\title{
SUMMARY OF THE SOUTHWEST ALLUVIAL BASINS, REGIONAL AQUIFER-SYSTEM ANALYSIS, SOUTH-CENTRAL ARIZONA AND PARTS OF ADJACENT STATES
}

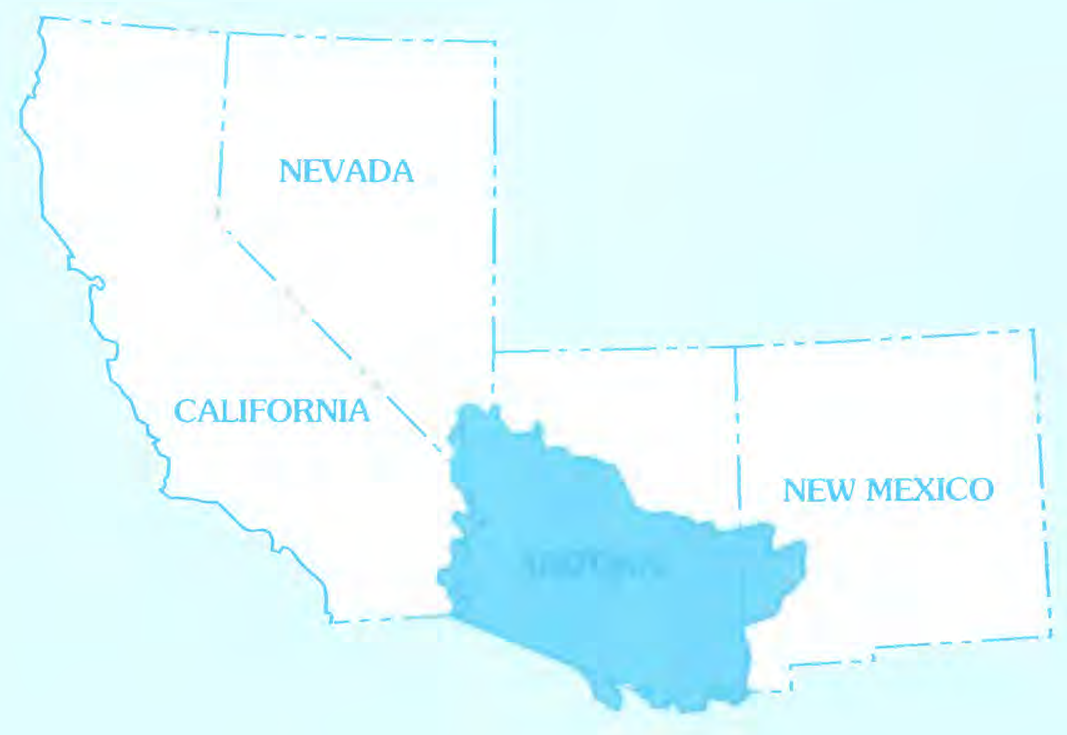


Instructions on ordering publications of the U.S. Geological Survey, along with prices of the last offerings, are given in the currentyear issues of the monthly catalog "New Publications of the U.S. Geological Survey." Prices of available U.S. Geological Survey publications released prior to the current year are listed in the most recent annual "Price and Availability List." Publications that are listed in various U.S. Geological Survey catalogs (see back inside cover) but not listed in the most recent annual "Price and Availability List" are no longer available.

Reports released through the NTIS may be obtained by writing to the National Technical Information Service, U.S. Department of Commerce, Springfield, VA 22161; please include NTIS report number with inquiry.

Order U.S. Geological Survey publications by mail or over the counter from the offices given below.

\section{BY MAIL}

\section{Books}

Professional Papers, Bulletins, Water-Supply Papers, Techniques of Water-Resources Investigations, Circulars, publications of general interest (such as leaflets, pamphlets, booklets), single copies of Earthquakes \& Volcanoes, Preliminary Determination of Epicenters, and some miscellaneous reports, including some of the foregoing series that have gone out of print at the Superintendent of Documents, are obtainable by mail from

\section{U.S. Geological Survey, Information Services Box 25286, Federal Center Denver, CO 80225}

Subscriptions to periodicals (Earthquakes \& Volcanoes and Preliminary Determination of Epicenters) can be obtained ONLY from the

\section{Superintendent of Documents Government Printing Office Washington, DC 20402}

(Check or money order must be payable to Superintendent of Documents )

\section{Maps}

For maps, address mail orders to

\section{U.S. Geological Survey, Map Distribution Box 25286, Bldg. 810, Federal Center Denver, CO 80225}

Residents of Alaska may order maps from

U.S. Geological Survey, Earth Science Information Center 101 Twelfth Ave., Box 12 Fairbanks, AK 99701

\section{OVER THE COUNTER}

\section{Books and Maps}

Books and maps of the U.S. Geological Survey are available over the counter at the following U.S. Geological Survey offices, all of which are authorized agents of the Superintendent of Documents.

- ANCHORAGE, Alaska-4230 University Dr, Rm. 101

- LAKEWOOD, Colorado-Federal Center, Bldg. 810

- MENLO PARK, California-BIdg. 3, Rm. 3128, 345 Middlefield $\mathrm{Rd}$.

- RESTON, Virginia-National Center, Rm. 1C402, 12201 Sunrise Valley Dr.

- SALT LAKE CITY, Utah-Federal BIdg., Rm. 8105, 125 South State St

- SPOKANE, Washington-U.S. Post Office Bldg., Rm. 135 , W. 904 Riverside Ave.

- WASHINGTON, D.C.-Main Interior Bldg., Rm. 2650, 18th and C Sts., NW.

\section{Maps Only}

Maps may be purchased over the counter at the U.S. Geological Survey offices:

- FAIRBANKS, Alaska-New Federal Building, 101 Twelfth Ave.

- ROLLA, Missouri-1400 Independence Rd.

- STENNIS SPACE CENTER, Mississippi-BIdg. 3101 
Summary of the Southwest Alluvial Basins, Regional Aquifer-System Analysis, South-Central Arizona and Parts of Adjacent States

BY T.W. ANDERSON

REGIONAL AQUIFER-SYSTEM ANALYSIS-

SOUTHWEST ALLUVIAL BASINS, ARIZONA AND ADJACENT STATES

U.S. GEOLOGICAL SURVEY PROFESSIONAL PAPER 1406-A

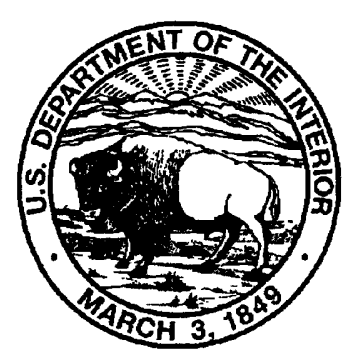

UNITED STATES GOVERNMENT PRINTING OFFICE, WASHINGTON: 1995 


\section{U.S. DEPARTMENT OF THE INTERIOR}

\section{BRUCE BABBITT, Secretary}

\section{U.S. GEOLOGICAL SURVEY}

\section{Gordon P. Eaton, Director}

Any use of trade, product, or firm names in this publication is for descriptive purposes only and does not imply endorsement by the U.S. Government

Anderson, T.W. (Thomas Warren), 1940-

Library of Congress Catologing-in-Publication Data

Summary of the Southwest Alluvial basins, regional aquifer-system analysis, south-central Arizona and parts of adjacent states / by T.W. Anderson.

p. - (Regional aquifer-system analysis-southwest Alluvial basins, Arizona and adjacent states) (U.S. Geological Survey professional paper ; 1406-A)

Includes bibliographical references.

Supt. of Docs. no.: I 19. 16:1406-A

1. Aquifers-Arizona. 2. Groundwater flow-Arizona. 3. Water chemistry. I. Series. II. Series: U.S. Geological Survey professional paper ; $1406-\mathrm{A}$.

GB1199.3A7A55 1994

$553.7^{\prime} 9^{\prime} 09791-\mathrm{dc} 20$ 


\section{FOREWORD}

\section{THE REGIONAL AQUIFER-SYSTEM ANALYSIS PROGRAM}

The Regional Aquifer-System Analysis (RASA) Program was started in 1978 following a congressional mandate to develop quantitative appraisals of the major ground-water systems of the United States. The RASA Program represents a systematic effort to study a number of the Nation's most important aquifer systems, which in aggregate underlie much of the country and which represent an important component of the Nation's total water supply. In general, the boundaries of these studies are identified by the hydrologic extent of each system and accordingly transcend the political subdivisions to which investigations have often arbitrarily been limited in the past. The broad objective for each study is to assemble geologic, hydrologic, and geochemical information, to analyze and develop an understanding of the system, and to develop predictive capabilities that will contribute to the effective management of the system. The use of computer simulation is an important element of the RASA studies, both to develop an understanding of the natural, undisturbed hydrologic system and the changes brought about in it by human activities, and to provide a means of predicting the regional effects of future pumping or other stresses.

The final interpretive results of the RASA Program are presented in a series of U.S. Geological Survey Professional Papers that describe the geology, hydrology, and geochemistry of each regional aquifer system. Each study within the RASA Program is assigned a single Professional Paper number, and where the volume of interpretive material warrants, separate topical chapters that consider the principal elements of the investigation may be published. The series of RASA interpretive reports begins with Professional Paper 1400 and thereafter will continue in numerical sequence as the interpretive products of subsequent studies become available.

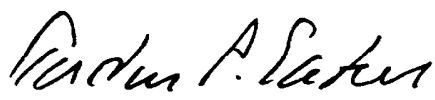

Gordon P. Eaton Director 



\section{CONTENTS}

Abstract

Introduction -

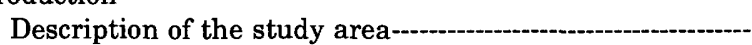

Southwest Alluvial Basins,

Regional Aquifer-System Analysis

Geohydrology

Physical setting

Geologic setting

Geohydrologic units

Geophysical studies

Hydrologic properties

Categorization of basins

Regional ground-water flow system

Occurrence and movement of ground water
Page

A1

2

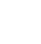

2

4

4

4

5
Regional ground-water flow system-Continued

Predevelopment flow system --

Development flow system - -

Geochemistry--

Dissolved solids and other characteristics -.-.--.---.--- 20

Ground-water chemistry types --_- 21

Trace elements -- 21

Geochemical models--._-_._-_._- 21

Water-resources development--.-.- 22

History of development -..._- 22

Effects of development -...-_- 23

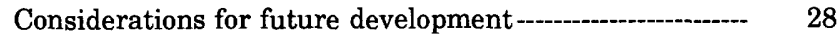

Selected references -- 30

\section{ILLUSTRATIONS}

FIGURE 1. Map showing Basin and Range physiographic province and the Southwest Alluvial Basins study area-

2. Sketch showing generalized section and description of principal hydrogeologic units in basins of the study area --------

3, 4. Graphs showing:

3. Approximate range in hydraulic conductivity for the three alluvial facies differentiated by relative grain size

4. Approximate range in specific yield for the three alluvial facies differentiated by relative grain size -

5-7. Maps showing:

5. Grouping of basins based on geohydrologic factors

位

6. Basins for which ground-water flow and geochemical models were developed -

7. Predevelopment ground-water flow conditions and pattern of interbasin flow --13

8. Sketch showing typical predevelopment inflow and outflow components in the alluvial basins-a

9. Graphs showing relation of estimated mountain-front recharge in a basin to total precipitation on the basin and total precipitation greater than 8 inches -

10. Graph showing annual ground-water pumpage, 1915-80

11. Diagram showing volume of water stored in the basin-fill aquifers to a depth of 1,200 feet below land surface, total volume pumped in 1915-80, and estimated net ground-water depletion-

12, 13. Maps showing:

12. Areas of water-level decline from the beginning of development through 1980

13. Ground-water flow system in Stanfield basin, 1923 and 1976-77

14. Photograph showing earth-fissure system more than 8 miles long, near Eloy, Arizona

15. Graphs showing generalized relation between increasing pumpage and changes in water-budget components

\section{TABLE}

TABLE 1. Estimates of water budget before development 
CONVERSION FACTORS AND VERTICAL DATUM

Multiply inch-pound units

foot $(\mathrm{ft})$

square foot $\left(\mathrm{ft}^{2}\right)$

foot squared per day $\left(\mathrm{ft}^{2} / \mathrm{d}\right)$

foot per mile $(\mathrm{ft} / \mathrm{mi})$

acre

mile (mi)

square mile $\left(\mathrm{mi}^{2}\right)$

cubic mile $\left(\mathrm{mi}^{3}\right)$

foot per second $(\mathrm{ft} / \mathrm{s})$

cubic foot per second $\left(\mathrm{ft}^{3} / \mathrm{s}\right)$

acre-foot (acre-ft)

gallon per minute (gal/min)
By

To obtain metric units

25.40

0.3048

0.0929

0.0929

0.1894

0.4047

1.609

2.590

4.168

0.3048

0.02832

0.001233

0.06309 millimeter $(\mathrm{mm})$

meter (m)

square meter $\left(\mathrm{m}^{2}\right)$

meter squared per day $\left(\mathrm{m}^{2} / \mathrm{d}\right)$

meter per kilometer $(\mathrm{m} / \mathrm{km})$

square hectometer $\left(\mathrm{hm}^{2}\right)$

kilometer $(\mathrm{km})$

square kilometer $\left(\mathrm{km}^{2}\right)$

cubic kilometer $\left(\mathrm{km}^{3}\right)$

meter per second $(\mathrm{m} / \mathrm{s})$

cubic meter per second $\left(\mathrm{m}^{3} / \mathrm{s}\right)$

cubic hectometer $\left(\mathrm{hm}^{3}\right)$

liter per second $(\mathrm{L} / \mathrm{s})$

In this report, temperature in degrees Celsius $\left({ }^{\circ} \mathrm{C}\right)$ can be converted to degrees Fahrenheit $\left({ }^{\circ} \mathrm{F}\right)$ by the following equation:

${ }^{\circ} \mathrm{F}=1.8 \times\left({ }^{\circ} \mathrm{C}+32\right)$

Sea Level: In this report, "sea level" refers to the National Geodetic Vertical Datum of 1929 (NGVD of 1929)-a geodetic datum derived from a general adjustment of the first-order level nets of both the United States and Canada, formerly called "Sea Level Datum of 1929." 


\title{
SUMMARY OF THE SOUTHWEST ALLUVIAL BASINS, REGIONAL AQUIFER-SYSTEM ANALYSIS, SOUTH-GENTRAL ARIZONA AND PARTS OF ADJACENT STATES
}

\author{
By T.W. ANderson
}

ABSTRACT

In 1979, the U.S. Geological Survey began the Southwest Alluvial Basins, Regional Aquifer-System Analysis study to evaluate the availability of water resources, functioning of the alluvial-aquifer systems, aquifer properties, water-quality and geochemical characteristics, and the interrelation of the individual ground-water basins in a regional hydrologic system. Results of this study were published in a series of reports that described (1) the geohydrology of the alluvial basins, (2) the geochemistry of ground water, (3) the simulation of ground-water systems in the alluvial basins, and (4) a summary of the information presented in the other three reports (this report).

The 82,000-square-mile Southwest Alluvial Basins, Regional Aquifer-System Analysis study area contains 72 basins. Each basin was grouped into one of five broad categories on the basis of geohydrologic character of the aquifer material and total annual downvalley flow through the basin. The interrelation of these factors and the response of the systems to pumping stress are similar among basins of a particular group. The groups are labeled southeast, central, west, Colorado River, and highland.

Unconsolidated alluvial deposits form the principal aquifers of the area. In contrast, the surrounding bedrock of the mountains can be considered impermeable. The basins are filled with alluvial deposits that range from a few thousand feet to more than 10,000 feet in thickness. In almost all basins, the general vertical sequence of sedimentary units includes, in ascending order, pre-Basin and Range rocks, lower and upper basin fill, and stream alluvium. Each unit has different physical, geologic, and hydrologic properties largely because of differences in the depositional environment and source area of the sedimentary material. In places, the alluvial deposits include a range of grain sizes from clay to gravel and can be unconsolidated to well consolidated within a basin. The alluvial deposits are hydraulically interconnected and form a single aquifer system within each basin.

The alluvial-basin aquifers serve principally as reservoirs for the storage of water. An estimated 900 million acre-feet of recoverable ground water was stored in the upper 1,200 feet of alluvial deposits prior to development. Outflow from one basin as surface flow, groundwater underflow, or a combination of both serves as inflow to the next basin downgradient. The quantity of inflow entering and outflow leaving the basins of the study area annually is estimated to have been about 2.5 million acre-feet prior to development. The basins are aligned in a dendritic pattern matching the surface-water drainage. Large-scale development in one basin could affect inflow to downgradient basins and outflow from upgradient basins.

The chemical quality of ground water generally is suitable for most uses in much of the area. Dissolved-solids concentrations range from about 300 to 1,000 milligrams per liter in most basins; locally, dissolved-solids concentrations are from 1,000 to more than 10,000 milligrams per liter. Dissolution reactions and, in a few places, evapotranspiration are principal causes of dissolved-solids concentrations in excess of about 1,000 milligrams per liter. In small parts of several basins, trace elements are present in ground water in concentrations that exceed standards for public supply and certain agricultural uses.

Use of water resources in the area has resulted in depletion of surface flow in several basins and overdraft of ground water in most developed basins. In places, water levels have declined more than 400 feet because of withdrawals in excess of natural recharge. Water-level declines of 50 to 200 feet are common in developed basins. From the time development began through 1980 , an estimated 184 million acrefeet of ground water has been withdrawn. Nearly 50 percent of this historical pumpage represents net depletion of ground-water storage. The other 50 percent of this pumpage was supplied by a reduction of streamflow and evapotranspiration or increases in recharge as a result of increased infiltration of streamflow and return of excess irrigation water. The regional flow system was altered as a result of development. In 1980, discharge exceeded recharge in most developed basins. Ground-water flow rates and directions have been altered and the flow direction has been reversed in parts of a few basins. The result has been capture of part or all of the former natural discharge. Near Tucson, selected reaches of formerly perennial streams now flow only in response to precipitation because of extensive ground-water development and associated lowering of the water table. The change in the basin flow system depends on the geohydrologic setting, which is one factor incorporated into a system of basin categorization for this study. The changes associated with water-resources development, therefore, are predictable and are related to basin category.

Associated with the water-level declines and changes in basin flow components are ancillary problems of decreasing aquifer productivity with depth, variable water quality with depth, and increased incidence of land subsidence and earth fissuring. Land subsidence and the occurrence of earth fissures have been 
documented in highly developed parts of central Arizona and are related to ground-water withdrawal and associated water-level declines. Earth fissures have occurred since about 1927. A fissure system near Eloy, Arizona, is more than 8 miles long and has had vertical offset of about 3 feet.

Results of ground-water flow modeling indicate that the effect of development on the ground-water systems of the individual basins and the changes in magnitude of individual flow components generally are predictable for each group of basins. Sensitivity analyses of ground-water flow models indicate that a relation exists between basin category and sensitivity of the models to selected properties. The properties are affected by the degree of development in the basin, the geologic setting within the basin, and the magnitude of predevelopment downvalley flow. Information transfer among basins of a particular group proved to be applicable and facilitated the development and calibration of ground-water flow models. Geochemical models also provided a means of verifying existing conceptual models of ground-water flow systems and valuable insight into the significance and magnitude of components of the basin water budgets.

\section{INTRODUCTION}

Alluvial basins in south-central Arizona and parts of adjacent States contain aquifers that store and yield large quantities of ground water. In many basins, the aquifers have been the principal source of water to support economic development, which has been based predominantly on agriculture. In 1979, the U.S. Geological Survey (USGS) began a study of the southwest alluvial basins, as part of its nationwide Regional Aquifer-System Analysis (RASA) Program, to evaluate the status of knowledge available to define the extent and character of the aquifers, to document the effects of development on the water resources, and to explore similarities and differences among the many basinaquifer systems of the region.

\section{DESCRIPTION OF THE STUDY AREA}

The study area includes about $82,000 \mathrm{mi}^{2}$ in arid to semiarid southern and central Arizona and parts of California, Nevada, New Mexico, and Mexico (fig. 1). The study area includes the surface-water drainage of the Colorado River between Hoover Dam and the international boundary near Yuma. The San Bernardino and Douglas basins in southeastern Arizona and parts of several basins in southwestern Arizona also are included, although these basins drain to Mexico. Also included are the Willcox basin in the southeastern part of Arizona and Hualapai Valley in the northwestern part (fig. 1), both of which have internal surface-water drainages. The area contains 72 basins that are virtually independent hydrologic entities that share common geologic and hydrologic characteristics. The boundaries between basins correspond to surface-water drainage divides, ground-water divides, areas of minimal interbasin connection, and, in a few instances, sociopolitical boundaries.

The area is characterized by wide, gently sloping plains whose continuity is broken by sharply rising mountains. The plains are the surface of the alluvial deposits that fill the basins. The alluvial deposits range from a few thousand to more than $10,000 \mathrm{ft}$ thick, include grain sizes from clay to gravel, and can be unconsolidated to well consolidated within a basin. The alluvial deposits are hydraulically interconnected and form a single aquifer system in each basin. The sediments that fill a basin are considered an aquifer system in accordance with the definition of Poland and others (1972). The basin-fill sediments probably include several permeable beds separated by finegrained confining units. In general, all the saturated sediments were hydraulically connected prior to development. As a result of large-scale withdrawals, however, variable degrees of hydraulic separation between permeable beds are indicated in some basins on the basis of differences in hydraulic head. Large quantities of ground water are stored in these aquifer systems. The occurrence and movement of ground water are influenced by the geology, physiography, and climate in the individual basins, which differ widely throughout the area.

\section{SOUTHWEST ALLUVIAL BASINS, REGIONAL AQUIFER-SYSTEM ANALYSIS}

The primary purpose of the Southwest Alluvial Basins, Regional Aquifer-System Analysis (Swab/RASA) study was to develop a better general understanding of the extent and workings of the hydrologic systems of alluvial basins in south-central Arizona and parts of adjacent States (Anderson, 1980). Goals included development of quantitative descriptions of the (1) physical framework of the aquifers, (2) predevelopment ground-water conditions, and (3) aquifer-system responses to development as related to the controlling geologic and hydrologic conditions. Numerical and geochemical models were the principal tools used in analyzing the geohydrologic systems; the models also provide predictive capabilities to explore and evaluate water-resources development options.

An initial hypothesis of the project was that certain characteristics and relations are common to many basins or subsets of basins. The strategy was to look in detail at selected basins that have an extensive data base and that typify a subset of basins having similar hydrologic characteristics. Information from basins in which the geohydrologic systems are well documented 

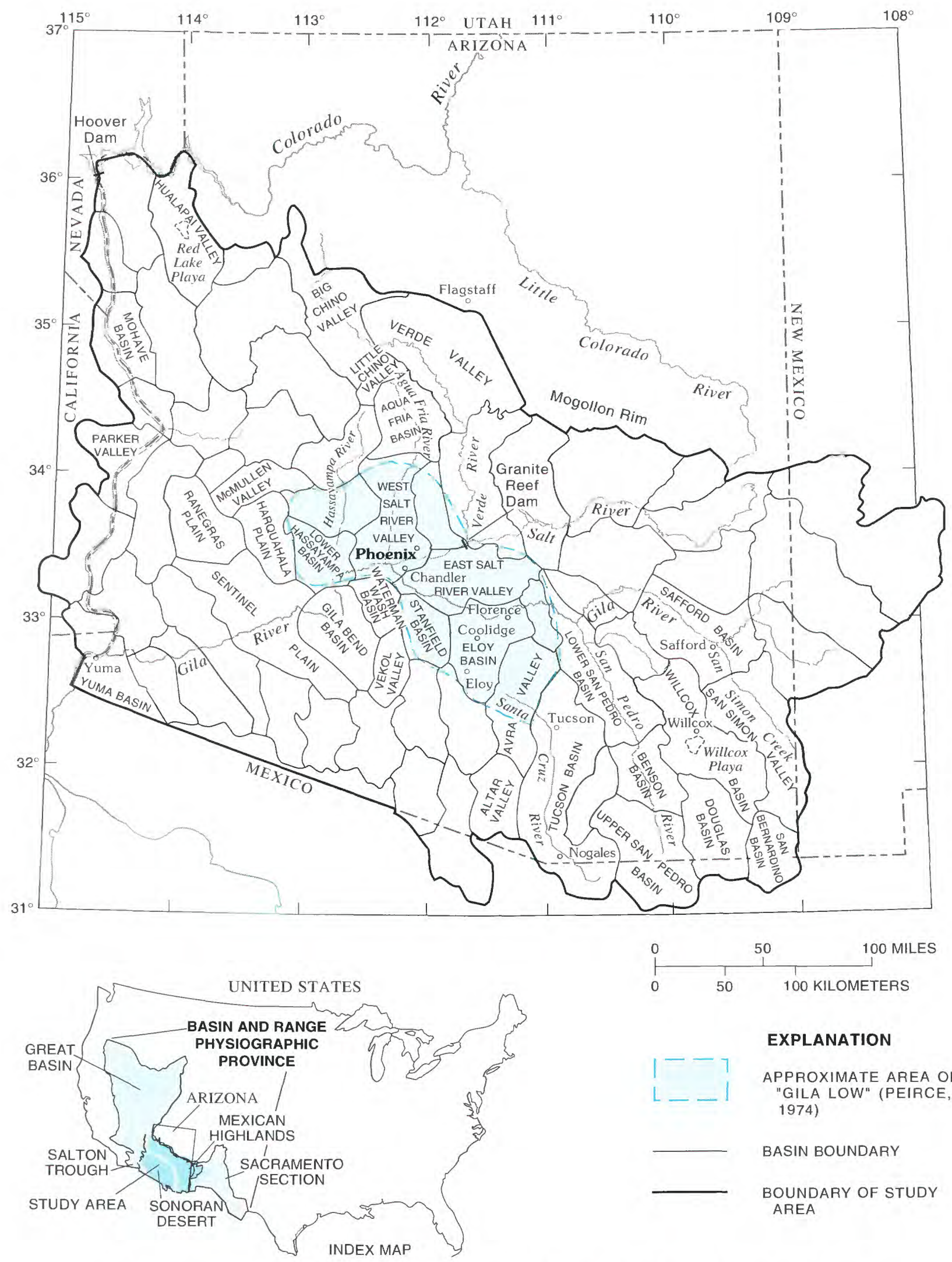

\section{EXPLANATION}

APPROXIMATE AREA OF "GILA LOW" (PEIRCE, 1974)

BASIN BOUNDARY

BOUNDARY OF STUDY AREA

FIGURE 1.-Basin and Range physiographic province and the Southwest Alluvial Basins study area. 
was transferred to hydrologically similar basins for which only sparse data are available and evaluated using numerical or geochemical modeling. This approach served as an aid to describe and analyze the geohydrologic systems of all basins. For the most part, the study used existing data, which were accumulated from various State, Federal, and local water-resources agencies. Existing data were supplemented through the collection of additional water- and rock-chemistry data and through field application and testing of geophysical-exploration techniques. Lithofacies maps were compiled for many basins to evaluate geologic and lithologic similarities.

The results of the Southwest Alluvial Basins, RASA study are summarized in this report. Chapters B, C, and D in Professional Paper 1406 describe detailed results of the study. Chapter B (Anderson and others, 1992) discusses the geohydrology of the alluvial basins and presents the general system of basin categorization, estimates of predevelopment water-budget components of each basin, and a history of ground-water development and associated effects. Chapter C (Robertson, 1991) describes the water quality and geochemistry of the aquifer systems. Chapter D (Anderson and Freethey, in press) discusses the numerical models developed and used to simulate ground-water flow in selected specific basins and in generalized basins representing average physical and hydrologic conditions for several categories of basins.

In addition to the Professional Paper series, about 50 reports were produced as a result of this study. All reports produced by the project staff, contractors, and cooperators are listed in the selected references of this report.

\section{GEOHYDROLOGY}

The Swab/RASA study area is characterized by a series of alternating horst and graben features that make up the mountain ranges and basins that typify the Basin and Range physiographic province. The mountain ranges consist of nearly straight segments of consolidated rocks that are more or less parallel, predominantly trending in a north to northwest direction. The mountain ranges separate the area into a series of sediment-filled basins, which are the subject of this study.

\section{PHYSICAL SETTING}

The study area includes extensive parts of the Sonoran Desert and Mexican Highlands sections of the
Basin and Range physiographic province as defined by Fenneman (1931; see fig. 1, this report). The basins are structural depressions that were subsequently filled with alluvial material mostly eroded from the surrounding mountains. Each basin is characterized by a gently sloping alluvial plain enclosed or partly enclosed by mountain ranges. Basins of the Sonoran Desert section generally are oval shaped and consist of about 70 percent basin floor and 30 percent mountains. Basins of the Mexican Highlands section tend to be longer and narrower than those of the Sonoran Desert section and consist of about 50 percent basin floor and 50 percent mountains. Landsurface altitude of the basin floors increases from less than $500 \mathrm{ft}$ above sea level in the southwest to more than $4,000 \mathrm{ft}$ in the northeast. Altitudes of the mountains range from about $1,000 \mathrm{ft}$ to more than $10,000 \mathrm{ft}$ above sea level. Precipitation, which increases in direct proportion to land-surface altitude, ranges from about $3 \mathrm{in} . / \mathrm{yr}$ near Yuma in the southwest to more than $30 \mathrm{in} . / \mathrm{yr}$ in the headwaters of the Gila, Salt, and Verde Rivers in the northeast (fig. 1). Average annual evaporation and length of growing season increase from the northeast toward the southwest as a function of the trend toward a hotter and drier climate in the lower altitude, more arid parts of the area.

As part of the process of evaluating basin similarities and developing basin categories, many physical and hydrologic characteristics of individual basins were measured. For all 72 basins, such characteristics as length, width, total area, area of alluvial material, average land-surface slope of the alluvial material, average annual precipitation on the basin, average predevelopment slope of the water table, and many others, were measured or calculated. Many derivative characteristics were subsequently calculated, such as length-width ratios and land-surface and water-table slope ratios. These data were tested using a statistical-analysis program to determine if correlations existed between various properties. In general, this process proved unsuccessful; it did not result in significant positive findings and did not facilitate the categorization process. The only statistically significant correlation that resulted was between average annual precipitation and altitude of land surface.

\section{GEOLOGIC SETTING}

The mountains of the study area consist of igneous, metamorphic, and sedimentary rocks that range in age from Precambrian to Cenozoic (Dane and Bach- 
man, 1965; Wilson and others, 1969). The rocks are chiefly granite, gneiss, schist, and volcanic types. Sedimentary rocks make up a small percentage of the mountains in the southeastern part of the study area and near the north boundary. The igneous, metamorphic, and sedimentary rocks that make up the mountains also form the lateral and underlying boundaries of the alluvial-basin aquifers.

The basins were formed during middle to late Miocene time Basin and Range structural disturbance. The structural disturbance occurred between 15 and 10 m.y. (million years) ago in the western part of the area (Shafiqullah and others, 1980) and between 12 and 10 m.y. ago in the eastern part (Scarborough and Peirce, 1978). Movement along high-angle normal faults downdropped basins in relation to the mountain masses and resulted in a series of generally north- to northwest-trending basins. Basin subsidence was a gradual process that was accompanied by deposition of locally derived sediment in internally drained basins. This closed-drainage environment resulted in the gradational pattern of coarse-grained sediment near the mountains and fine-grained sediment near the basin center exhibited in the basin-fill units. The depositional centers of the basins typically contain evaporite deposits, such as gypsum, anhydrite, and halite, in addition to fine-grained sediment.

On the basis of two-dimensional gravity modeling results (Oppenheimer and Sumner, 1980), the deepest basins are those in the central part of Arizona. Depth to underlying bedrock may exceed $10,000 \mathrm{ft}$ in most of these basins, which are part of the "Gila Low" defined by Peirce (1974) (fig. 1). This area is characterized by the presence of massive evaporite deposits in the basin fill and has been a center of deposition since the time of the Basin and Range structural disturbance. The area is still the focal point of a large part of the Gila River drainage. Major tributaries to the Gila River-the Santa Cruz, Agua Fria, and Hassayampa Rivers and the Salt River and its principal tributary, the Verde River (fig. 1)-all join the Gila River near Phoenix in the central part of the Gila Low. The drainage above this point includes 86 percent of the total Gila River drainage and 60 percent of the entire study area.

\section{GEOHYDROLOGIC UNITS}

The bedrock that underlies the basins and constitutes the mountains contains usable amounts of ground water only where extensively fractured or faulted. Such secondary permeability features may provide limited amounts of water, generally sufficient only for domestic and stock supplies. A regional ground-water flow system involving hydraulic interconnection through the bedrock does not exist in the bedrock as it does in the Great Basin section of the Basin and Range province in Nevada (Burbey and Prudic, 1991).

Basin subsidence and sediment deposition occurred at differing rates throughout the area. As a result, the thickness, areal extent, and grain size of the alluvial deposits are highly variable from basin to basin. The alluvial deposits are made up of clay- to gravelsized material that may be unconsolidated to well consolidated in a single basin. The general vertical sequence of sedimentary units that overlie the bedrock consists of (1) pre-Basin and Range rocks, (2) lower and upper basin fill, and (3) stream alluvium (fig. 2). The units are distinguishable on the basis of structural relation, degree of consolidation and deformation, source area of clasts, geologic age, and water-bearing characteristics, and they reflect different conditions and intervals of deposition. Ground water occurs in the interstitial voids of the alluvial deposits, and the deposits are hydraulically interconnected and form a single aquifer system in most basins. Although the geohydrologic setting of each basin is unique, general spatial patterns in the character, thickness, and extent of the units can be documented within groups of basins. This was a major factor upon which the basin categorization was based (Anderson and others, 1992).

The pre-Basin and Range rocks consist of moderately to well-consolidated continental sedimentary deposits that range from clay to gravel and include some volcanic rocks. The sediments were deposited prior to the disturbance that formed the general basin and range topography and are faulted and tilted similar to the underlying bedrock. The pre-Basin and Range rocks generally are deeply buried in the basins and are unconformably overlain by basin-fill sediment. Although a few wells penetrate the preBasin and Range rocks near the basin edges, little is known of their water-bearing character. Pre-Basin and Range rocks generally are well indurated and are not a productive water-bearing unit. Where highly fractured, however, the unit may yield large quantities of water to wells.

Basin-fill sediments, which constitute the principal aquifer system in most basins, were deposited in basins formed by the Basin and Range structural disturbance. The lower part of the basin fill is moderately to highly consolidated, has extensive basin-center fine-grained material, and typically contains evaporite deposits that range from disseminated gypsum to massive halite beds. Lower basin fill 
was deposited in topographically closed basins. Upper basin fill was deposited during a transition period in which the basin drainage evolved from closed to integrated. The upper basin fill is less consolidated, generally is thinner, and contains less finegrained sediment than the lower basin fill. Both lower and upper basin-fill units grade from coarsegrained sediment at the basin margins to finegrained sediment near the basin center.

Stream alluvium consists of unconsolidated clay- to boulder-size material that was deposited contemporaneously with the establishment of the present surfacedrainage system. Where saturated, stream alluvium is the most productive part of the aquifers.

The alluvial-aquifer system in most basins serves mainly as a reservoir for the storage of ground water. The volume of water in storage is large compared with the small quantity of flow occurring from basins of higher altitude to basins of lower altitude.

\section{GEOPHYSICAL STUDIES}

Several geophysical methods were used to evaluate subsurface geohydrologic conditions in basins in southern and central Arizona as a part of the Swab/RASA project (Tucci, 1989). Surface-geophysical methods, including gravity, seismic, and resistivity, were used to provide regional and local subsurface information. Borehole methods were used to provide information on lateral and vertical variations of geohydrologic conditions. The geophysical methods generally were applied in areas where additional geologic data were available that could be used to

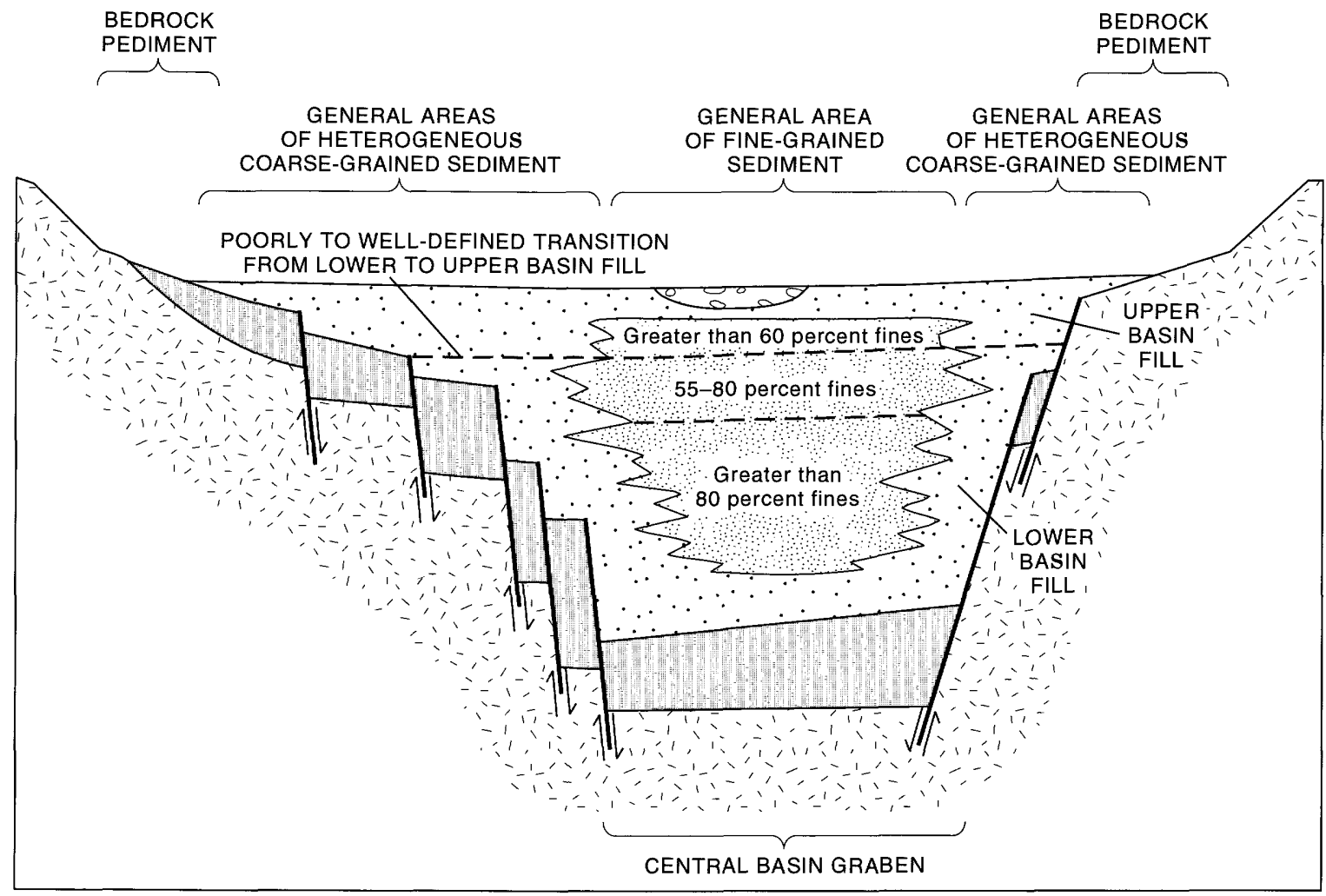

Not to scale

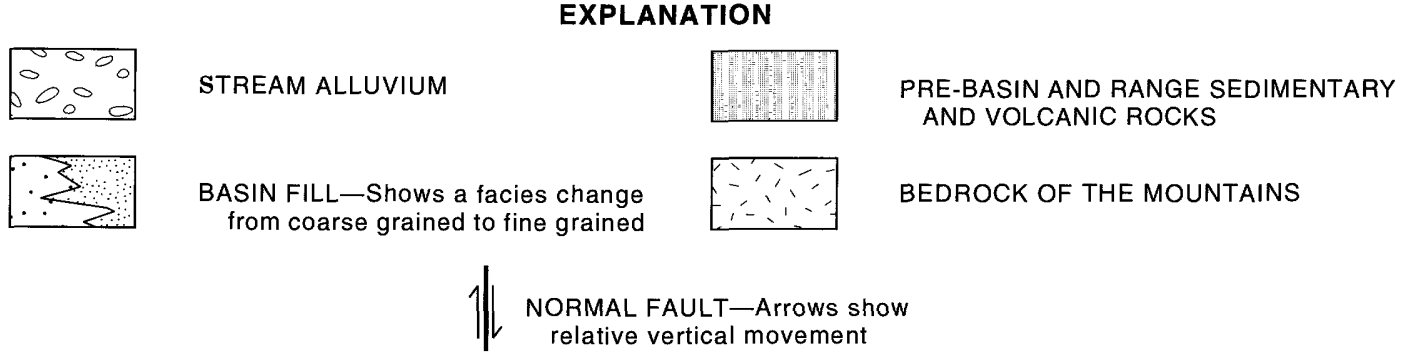

FIGURE 2.-Generalized section and description of principal hydrogeologic units in basins of the study area. 
correlate with and to evaluate the results of the geophysical methods.

Four general geohydrologic features or targets were identified for investigation using one or several geophysical methods. These targets were (1) basin structure, (2) basin stratigraphy, (3) hydrologic properties of the aquifer, and (4) depth to the water table. Structural targets included depth to the bedrock surface that defines the boundaries of the main water-bearing units and the location of buried faults in both bedrock and sediments. Stratigraphic targets included the contact between the upper and lower basin-fill units and the location of extensive fine-grained deposits in the basin fill. Porosity of basin-fill deposits, calculated from density values, was the hydrologic property sought from the borehole-gravity study.

Gravity data were used to develop a generalized depth-to-bedrock map for most of the Swab/RASA study area (Oppenheimer and Sumner, 1981). The gravity method was a useful reconnaissance tool in providing regional information because data collection is rapid and relatively inexpensive. Although this method provides useful information on basin size and shape, it cannot provide information on detailed subsurface stratigraphy.

Seismic refraction was used northwest of Tucson to locate the water table and to detect velocity variations in the sediment that may correspond to different basin-fill lithologic units. Bedrock was readily distinguished, and a buried fault could be inferred. Although expensive for large-scale regional investigations, this method can provide detailed subsurface information.

In Tucson basin and Avra Valley (fig. 1), electricalresistivity soundings were used to locate fine-grained deposits, which are characterized by resistivities of less than $10 \mathrm{ohm}$-meters (Tucci, 1984). Shallow bedrock also was readily detected, and faults were indicated by displacement of the bedrock. The method was not successful in locating the water table because of the heterogeneous nature of the basin fill. The method generally is less expensive than the seismic method and can provide detailed subsurface information.

Borehole-gravity data were obtained in six wells in four basins to determine the density of the basin fill. Density values calculated from borehole-gravity data

\begin{tabular}{|c|c|c|c|}
\hline Unit & Lithology & $\begin{array}{l}\text { Range in thickness, } \\
\text { in feet }\end{array}$ & $\begin{array}{l}\text { Range in hydraulic } \\
\text { properties }\end{array}$ \\
\hline Stream alluvium & $\begin{array}{l}\text { Unconsolidated alluvial deposits along major streams and washes; } \\
\text { ranges from boulders and gravel to minor amounts of lacustrine } \\
\text { clay; typically consists of well-sorted sandy gravel with some silt. }\end{array}$ & $\begin{array}{l}0 \text { to more than } \\
300\end{array}$ & $\begin{array}{l}\text { Only locally saturated. } \\
\text { Hydraulic conductivity, } \\
30-1,000 \text { feet per day. } \\
\text { Specific yield, } 15-25 \\
\text { percent. }\end{array}$ \\
\hline Upper basin fill & $\begin{array}{l}\text { Unconsolidated to moderately consolidated alluvial deposits. } \\
\text { Grades from coarse- to fine-grained sediments toward the center } \\
\text { of most basins; includes basin-center facies with greater than } 60 \\
\text { percent fine-grained silt and clay; also includes lake deposits and } \\
\text { basalt flows in a few basins. }\end{array}$ & $\begin{array}{l}\text { Less than } 100 \text { to } \\
1,000\end{array}$ & $\begin{array}{l}\text { Hydraulic conductivity, } \\
1-100 \text { feet per day. } \\
\text { Specific yield, } 3-25 \\
\text { percent. }\end{array}$ \\
\hline \multirow[t]{4}{*}{ Lower basin fill } & $\begin{array}{l}\text { Weakly to highly consolidated gravel, sand, silt, and clay and in } \\
\text { places contains interbedded to massive evaporites and volcanic } \\
\text { rocks. }\end{array}$ & & \multirow[t]{4}{*}{$\begin{array}{l}\text { Hydraulic conductivity, } \\
1-50 \text { feet per day. } \\
\text { Storage coefficient, } \\
10^{-5} \text { to } 10^{-1} \text {. }\end{array}$} \\
\hline & $\begin{array}{l}\text { Weakly to highly consolidated fanglomerate and alluvial } \\
\text { deposits found on the perimeter of most basins. In some } \\
\text { places grades rapidly into the fine-grained facies near major } \\
\text { basin faults; underlies the fine-grained facies in extensive } \\
\text { areas of many basins. }\end{array}$ & 0 to 1,000 & \\
\hline & $\begin{array}{l}\text { - Basin-center fine-grained facies, weakly to moderately } \\
\text { consolidated silt and clay, generally } 55 \text { to } 80 \text { percent fine- } \\
\text { grained sediments; contains few evaporite deposits. }\end{array}$ & 1,000 to 5,000 & \\
\hline & $\begin{array}{l}\text { - Basin-center fine-grained facies, moderately consolidated silt } \\
\text { and clay, greater than } 80 \text { percent fine-grained sediments; } \\
\text { gypsiferous in many places. Includes extensively } \\
\text { interbedded or massive evaporites and interbedded volcanics } \\
\text { in a few basins. }\end{array}$ & Less than 1,000 & \\
\hline $\begin{array}{l}\text { Pre-Basin and Range } \\
\text { sediments and } \\
\text { volcanics }\end{array}$ & $\begin{array}{l}\text { Moderately to highly consolidated fanglomerate and alluvial } \\
\text { deposits and interbedded volcanics that are structurally } \\
\text { disturbed. Range in composition from silt, clay, claystone, and } \\
\text { limestone to gravel and conglomerate and include interbedded } \\
\text { volcanics in places. }\end{array}$ & $\begin{array}{l}\text { Less than } 1,000 \\
\text { to } 15,000\end{array}$ & $\begin{array}{l}\text { Hydraulic conductivity, } \\
1-13 \text { feet per day. } \\
\text { Storage coefficient, } \\
6 \times 10^{-5} \text { to } 10^{-2} \text {. }\end{array}$ \\
\hline $\begin{array}{l}\text { Bedrock of the } \\
\text { mountains }\end{array}$ & \multicolumn{3}{|l|}{ Igneous, metamorphic, and sedimentary rocks. } \\
\hline
\end{tabular}


are not significantly influenced by casing, borehole roughness, or drilling-induced formation damage. Basin-fill densities ranged from 1.73 to 2.46 grams per cubic centimeter (Tucci and others, 1983) and are similar to those obtained by other investigators in Arizona and Nevada (Healey, 1970; Eaton and others, 1972; Mattick and others, 1973). Basin-fill density generally increases with increasing depth. Porosity of saturated basin fill calculated from the boreholegravity data range from 17 to 33 percent. Boreholegravity surveys are expensive but can be justified if detailed basin-fill density data are needed.

An integrated approach incorporating several geophysical methods can provide valuable geohydrologic information before an expensive and extensive program of exploratory drilling is initiated in a basin. Gravity data can be acquired to provide general information on basin shape and depth. Resistivity data can be used to aid in determining location, areal extent, and thickness of fine-grained deposits, particularly near the basin center. Seismic data can provide additional stratigraphic and water-table information. All three geophysical methods can provide structural information near the basin margins. Programs are readily available for computers and hand calculators to aid in the interpretation of the geophysical data.

\section{HYDROLOGIC PROPERTIES}

Ground-water movement and storage are controlled by the hydrologic properties of an aquifer or confining unit. The hydrologic properties are, in turn, related to the textural characteristics, particularly average grain size of the material. The alluvial sediments that fill the basins generally can be grouped into three facies based on their textural character(1) the coarse-grained facies, (2) the fine-grained facies, and (3) the intermediate facies. The vertical transition from one facies to another is distinct in some places and difficult to discern in other places. Laterally, the transition may be distinct and occur abruptly or may be a gradational change from coarse to fine over a distance of many miles. The coarsegrained facies corresponds to stream alluvium (fig. 2), which is associated with the major surface drainages. Stream alluvium typically consists of well-sorted sand and gravel but also includes material ranging in size from silt to boulders. The fine-grained facies occurs in the lower and upper basin-fill units and consists of 55 percent or more of material less than 0.0625 millimeters in diameter. The intermediate facies also includes sediments of the lower and upper basin-fill units and is the part of the alluvial deposits not included in the fine- or coarse-grained facies. The intermediate facies consists of a heterogeneous, poorly sorted mixture of gravel, sand, silt, and clay. These three major alluvial facies of significantly different physical characteristics represent a first approximation of the hydrologic properties of the aquifers that control the ground-water flow system within each basin.

Because of its coarse-grained nature, stream alluvium can transmit and store large quantities of water. Hydraulic conductivity commonly ranges from about 30 to as much as $1,000 \mathrm{ft} / \mathrm{d}$ (fig. 3), and specific yield ranges from 15 to 25 percent (fig. 4). The stream alluvium was only locally saturated but was a significant factor in the predevelopment flow system. Although significant dewatering of the unit has occurred in response to development, it remains an important part of the aquifer system through its functional role of accepting and storing recharge from intermittent surface runoff.

The fine-grained facies has a large porosity and stores large quantities of water; however, wells finished in this facies have small yields because the hydraulic conductivity is small and water is not readily released from storage. The hydraulic conductivity typically is less than $10 \mathrm{ft} / \mathrm{d}$ on the basis of available aquifer-test data (fig. 3); specific yield probably ranges from less than 1 to 10 percent (fig. 4). The fine-

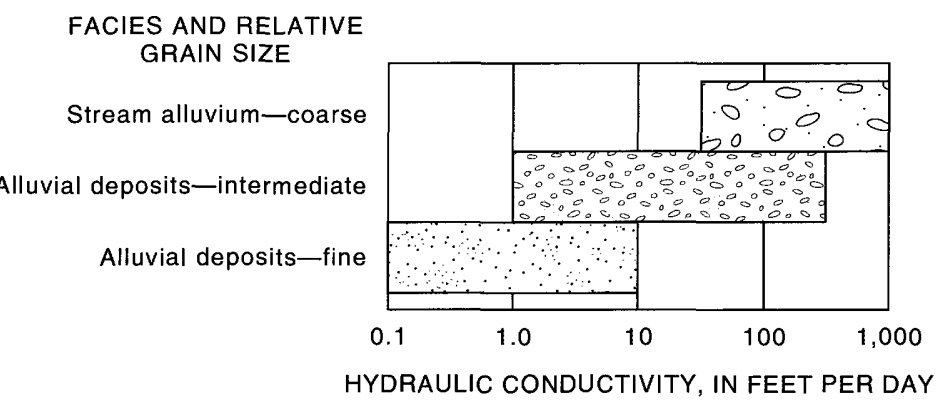

FIGURE 3.-Approximate range in hydraulic conductivity for the three alluvial facies differentiated by relative grain size.

FACIES AND RELATIVE GRAIN SIZE

Stream alluvium-coarse

Alluvial deposits-intermediate

Alluvial deposits-fine

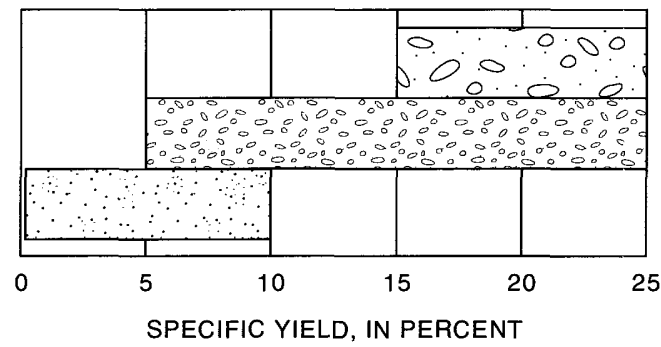

FIGURE 4.-Approximate range in specific yield for the three alluvial facies differentiated by relative grain size. 
grained facies in the lower and upper basin-fill units greatly influences the general movement of ground water. Because of the small vertical and horizontal hydraulic conductivity, a small quantity of water moves through the facies. The small rate at which water moves into and out of the fine-grained sediment limits well production and recharge rates. Perched-water zones have developed and overlie parts of the fine-grained facies and interbedded lenses of fine-grained sediment. Where distinct lateral changes in grain size occur from fine to coarse, pumped wells that penetrate the coarse-grained material may exhibit drawdown responses indicative of nearby no-flow boundaries. The distribution of the fine-grained facies influences ground-water quality; areas underlain by thick fine-grained facies also are prone to land subsidence, which accompanies drainage and inelastic compaction of the sediment.

Regional patterns of the occurrence of the basincenter fine-grained facies were documented as part of this study (Freethey and others, 1986). Three distinct types of fine-grained facies are present. Two types occur in the lower basin-fill unit and are (1) a silt and clay facies that consists of 80 - to 100-percent fine-grained material, which includes gypsum, gypsiferous mudstone, and massive evaporite deposits, and (2) a moderately fine-grained facies that consists of 55- to 80-percent silt and clay, which can include evaporite deposits. The third type occurs in the upper basin fill and consists of greater than 60-percent finegrained sediment in the basin centers; this type does not contain evaporite deposits.

The alluvial facies of intermediate grain size is the principal water-yielding facies of the basin-fill deposits. This facies includes a range from fine-grained to coarse-grained material and is much more heterogeneous than the other two facies. The hydraulic conductivity ranges from 1 to $300 \mathrm{ft} / \mathrm{d}$ (fig. 3 ), and specific yield ranges from 5 to 25 percent (fig. 4).

The water-bearing character of the deposits in the deep part of the alluvial basins is not known because development of water supplies from great depths has not occurred. Presumably, low porosity and permeability would physically limit ground-water development because of greater compaction and cementation of sediment at depths of several thousand feet. Information to define the water-bearing properties generally is not available for depths below about $2,000 \mathrm{ft}$.

\section{CATEGORIZATION OF BASINS}

The basins of the study area were categorized on the basis of similarities in geologic, hydrologic, and geochemical characteristics. Categorization was a means of grouping all basins so that the study of a selected few would provide information that could be transferred to other basins of the group. Details of the procedures used for the geohydrologic categorization are presented by Anderson and others (1992) and for the geochemical categorization by Robertson (1991). The two principal factors used for categorization were (1) the geohydrologic properties of the aquifer material and (2) the total annual downvalley flow through the basin. These factors largely control the manner in which the aquifer system responds to development. The general response of an aquifer system can be predicted by recognizing similarities in the controlling geohydrologic factors and the validity of information transfer between basins of a particular category. On the basis of the model results for several specific basins in each category, information transfer was determined to be a valid approach to analyzing system responses, provided that no major differences in geology or hydrology exist between the basin being analyzed and those basins from which the typical characteristics of the category were defined.

The principal geologic property that controls the occurrence and movement of ground water is the grain size of the sediment that makes up the basinfill aquifer system. Fine-grained sediments have the greatest control on the geohydrology because of their small hydraulic conductivity. The most important hydrologic factor in comparing the basin-fill aquifer systems is the total annual downvalley flow, which represents the total renewable water resources available on an annual basis prior to development. On the basis of areal similarities in grain size and downvalley flow, the basins were grouped into five categories: (1) southeast, (2) central, (3) west, (4) Colorado River, and (5) highland (fig. 5). The response of a groundwater system to the stresses of development will be similar among the basins of a particular category.

The understanding of the functioning of the ground-water system water-movement and direction and the response of the system to stresses - in each type of basin was aided by the development and application of ground-water flow models. Two types of ground-water flow models were developed and used; these are (1) specific-basin models and (2) basingroup models of generalized hydrologic systems that represent average conditions for basins of a particular category. Models of specific basins of the southeast, central, west, and Colorado River groups were developed to simulate actual physical systems and the documented system responses to historical development. Because of the absence of data, no models were developed of basins of the highland group. Each 

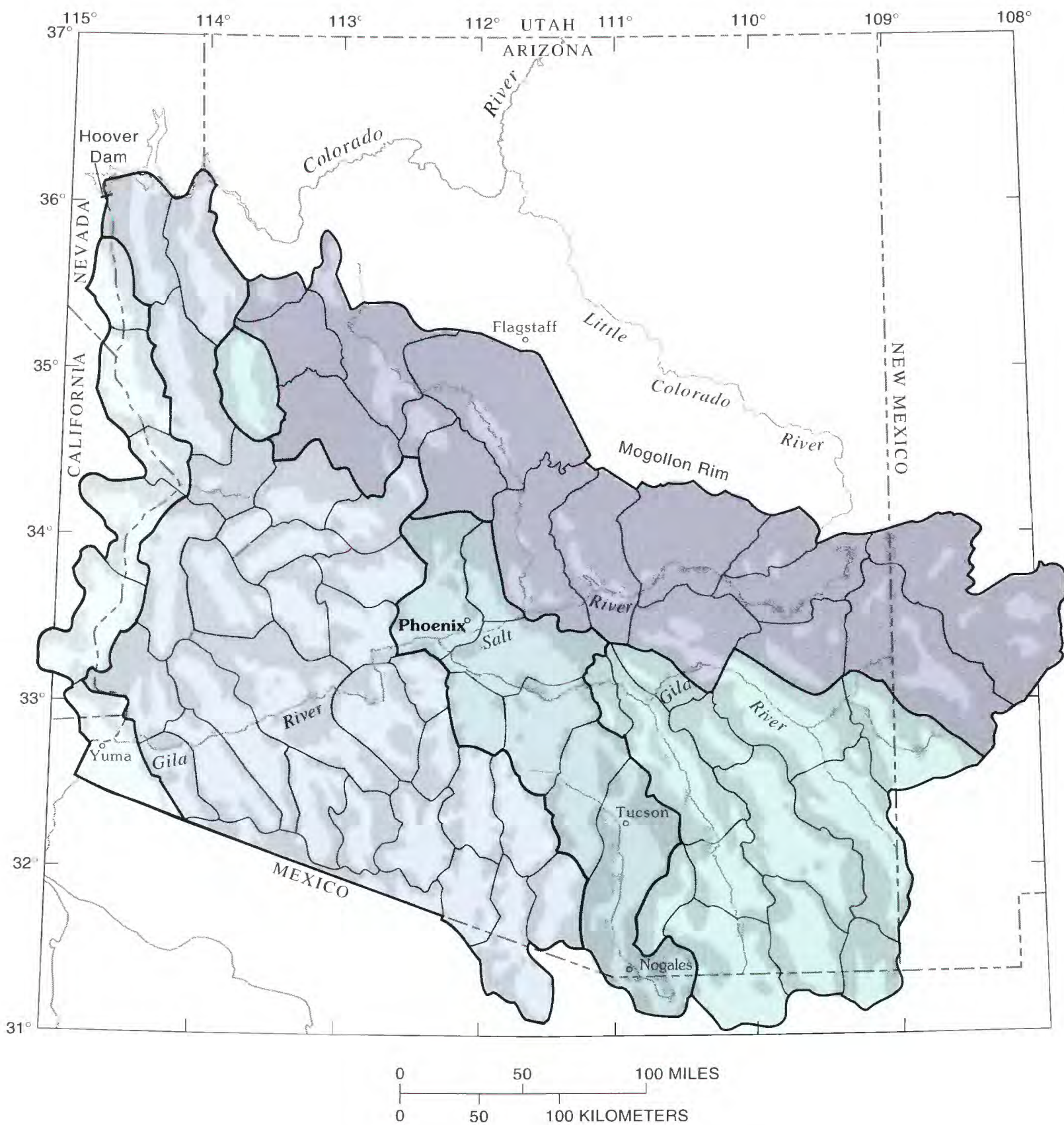

EXPLANATION

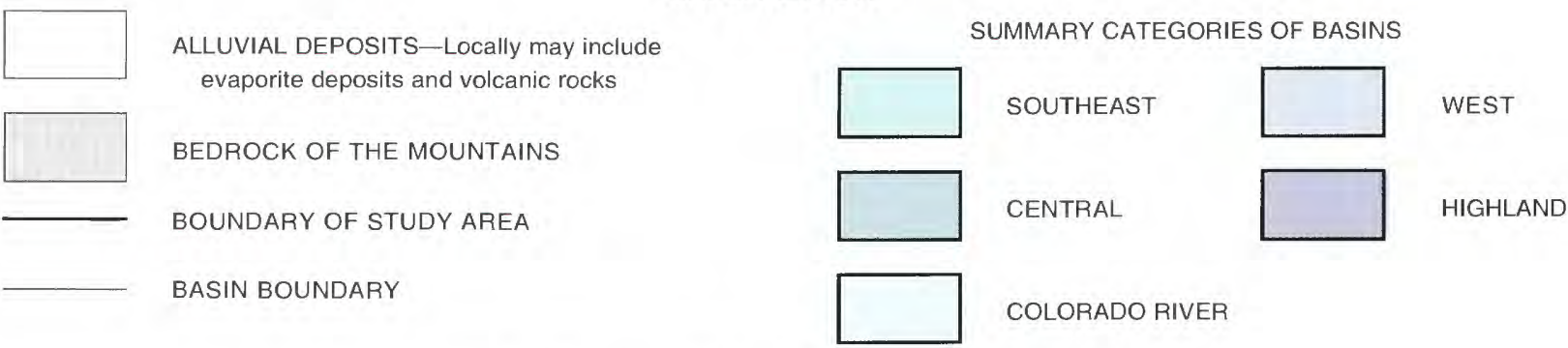

FIGURE 5.-Grouping of basins based on geohydrologic factors. 
specific-basin model was based on available data and geologic and hydrologic concepts developed from previous investigations. A total of 12 specific-basin mod- els were developed and were history matched to a predevelopment or an appropriate steady-state development condition (fig. 6). Ten of the specific-basin

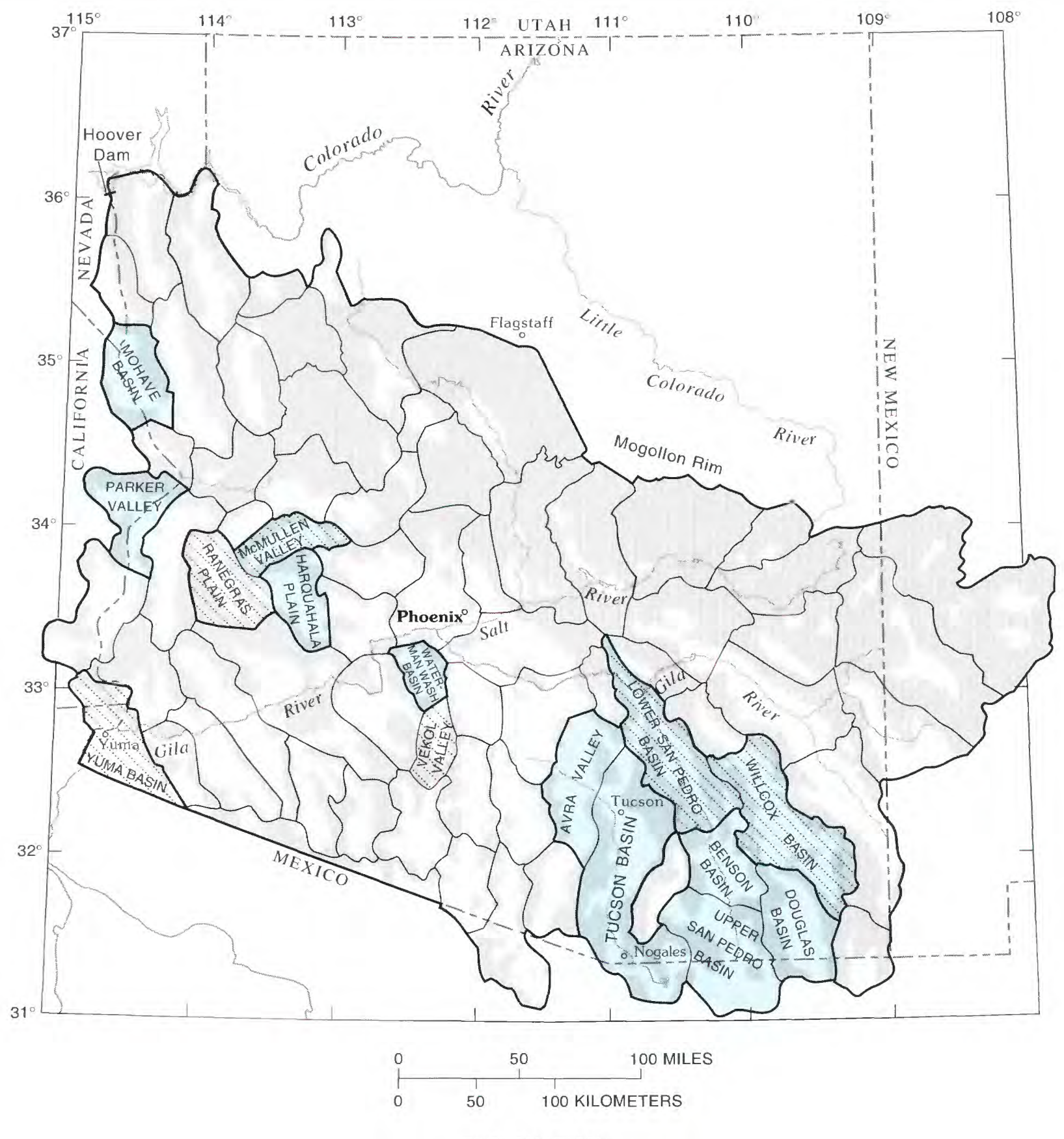

EXPLANATION

ALLUVIAL DEPOSITS-Locally may include evaporite deposits and volcanic rocks

BEDROCK OF THE MOUNTAINS

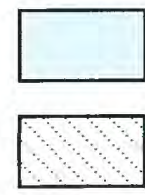

GROUND-WATER FLOW MODEL OF BASIN

GEOCHEMICAL MODEL OF BASIN 
models were further evaluated using available transient or development data.

The basin-group models were developed using average values of physical and hydrologic properties for groups of basins that have similar geohydrologic environments. The models were used to evaluate the significance of particular hydrologic properties or flow components on modeling results and to systematically explore sensitivity to variations in property values used in the models. Two basin-group models were developed, one representing average conditions for the southeast basin group and the other representing average conditions for the central and west basin groups.

All modeling was accomplished using the threedimensional finite-difference model described by Trescott (1975) and Trescott and Larson (1976). A quasi-three-dimensional approach was used in which the aquifer system is simulated as several layers. Each layer represented a vertical segment of the basin-fill aquifer connected hydraulically by a leaky confining layer, represented by a leakance coefficient, to allow vertical flow between layers. Information necessary for the models includes the areal extent and thickness of the aquifer, water-bearing properties of the aquifer such as horizontal and vertical hydraulic conductivity, specific storage, ranges and locations of ground-water recharge and discharge, and pumpage. Results from the models consist of simulated hydraulic heads at specified locations, depths, and times; a mass balance that represents the summation of flow into and out of the simulated system; and simulated change in storage.

The properties that are significant in development of ground-water flow models are related to (1) hydrologic boundaries, (2) flow components, and (3) values of hydrologic properties. Hydrologic boundaries represent the physical constraints on aquifer extent and include water-level configuration, aquifer bottom, and lateral boundaries. Flow components include recharge to and discharge from the aquifer and changes in storage in the aquifer. Hydrologic properties control the rate of movement and quantity of storage in the aquifer. The model represents a much generalized system that uses average property values for large segments of the aquifer. The high degree of spatial variability that exists in the actual system must be simplified for use in the model. Because of the differences in geohydrologic setting and because different properties may be more significant in each group of basins, numerical models have various levels of data requirements.

Basins of the southeast group for which groundwater flow models were developed are upper San Pedro, Benson, lower San Pedro, Willcox, and Douglas basins (fig. 6). These basin aquifers were simulated as two layers with an intervening leaky confining bed. Properties of particular significance include specific yield, interlayer leakance, the relation between evapotranspiration and depth to water, and pumpage quantity and location.

Basins of the central group for which ground-water flow models were developed are Tucson basin and Avra Valley (fig. 6). Models of the west group of basins were developed for Waterman Wash basin, Harquahala Plain, and McMullen Valley (fig. 6). These aquifer systems are best simulated using multiple layers. Recharge and discharge mechanisms are more important in the central group than in the west group because of their much larger magnitude. Storage depletion is common in both groups as a result of development, although some capture of discharge occurs in the central basins during the early phase of development. Location and magnitude of pumpage and values of specific yield are critical properties for use in models of basins of these two groups. Reliability of these data will determine the overall reliability of the simulation.

Basins of the Colorado River group for which ground-water flow models were developed are Parker Valley and Mohave basin (fig. 6). Because the hydrologic system of these basins is dominated by flow in the Colorado River, flow and aquifer-system properties related to shallow water-table conditions are most important. These properties include riverbed leakance, relation between evapotranspiration and depth to the water table, and return of excess applied irrigation water. Realistic ground-water flow models of these basins can be developed using a two-dimensional approach. Because of insufficient data, specificbasin models were not developed for the highland group, although they are assumed to be scaled-down versions of the Colorado River basins.

\section{REGIONAL GROUND-WATER FLOW SYSTEM}

The Southwest Alluvial Basins, RASA study area is composed of a series of ground-water reservoirs that are variably interconnected in a dendritic pattern closely parallel to that of the regional surface-water drainage (fig. 7). The surface-drainage network consists of the Colorado River; its principal tributary, the Gila River; and streams tributary to either the Colorado or Gila Rivers. Part of the area drains southward into Mexico, and two basins have internal surface drainage. Hualapai Valley in the northwestern part of Arizona, for the most part, drains to Red Lake Playa; the northernmost part of the valley 

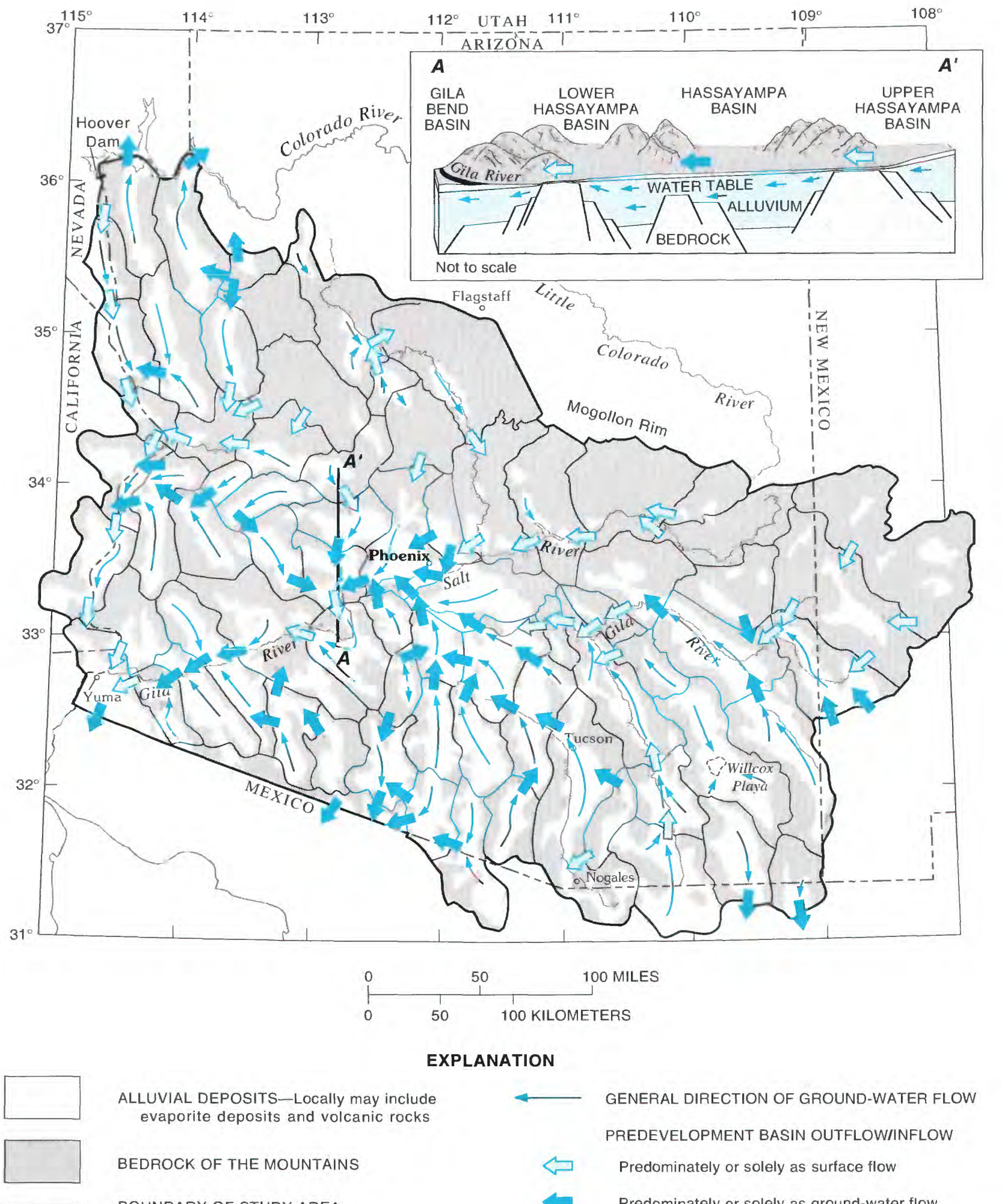

ALLUVIAL DEPOSITS-Locally may include evaporite deposits and volcanic rocks

BEDROCK OF THE MOUNTAINS

BOUNDARY OF STUDY AREA

BASIN BOUNDARY
GENERAL DIRECTION OF GROUND-WATER FLOW PREDEVELOPMENT BASIN OUTFLOWIINFLOW

$\leftrightarrow \quad$ Predominately or solely as surface flow

Predominately or solely as ground-water flow

FIGURE 7.-Predevelopment ground-water flow conditions and pattern of interbasin flow. 
drains directly to the Colorado River. Willcox basin in the southeast corner of Arizona drains to Willcox Playa. The infrequent surface flow that reaches the playa areas is discharged by evaporation. The ground-water system of Hualapai Valley is throughflowing and discharges into the Colorado River (Laney, 1979). The ground-water flow system of Willcox basin is internally drained, as is the surfacewater system. Prior to development, discharge occurred as evaporation and transpiration at Willcox Playa (Meinzer and Kelton, 1913).

The regional pattern of interbasin flow that existed prior to development is illustrated in figure 7. The degree of interconnection between basins and the quantity of flow from one basin into the next downgradient basin are highly diverse. Interbasin flow occurs as surface-water flow, ground-water flow, or a combination of surface-water and ground-water flow (fig. 7 , section $A-A^{\prime}$ ). Section $A-A^{\prime}$ extends from the upper Hassayampa basin southward to the Gila Bend basin. Three conditions, illustrated proceeding in the downstream direction, include discharge by a combination of surface-water and ground-water flow, by ground-water flow only, and by almost entirely surface flow. No general pattern, such as increased flow in the downstream direction from one basin to the next downgradient basin, was found. The major controls on the geohydrology of individual basins and groups of basins include the physiographic factors of altitude and climate and the geologic factors of structure and lithology of basin sediments. These factors influence the quantity of flow that occurs between basins and the mechanism(s) by which it occurs.

\section{OCCURRENCE AND MOVEMENT OF GROUND WATER}

Ground water generally occurs under unconfined conditions in the alluvial aquifers. Ground water is confined in some parts of several basins where extensive fine-grained deposits overlie the principal water-bearing unit. Locally confined conditions are exhibited where coarse- and fine-grained sediments interfinger. The extent of the areas exhibiting confined conditions depends on the lateral extent and continuity of the fine-grained confining bed. Significant variations in hydraulic head with depth indicate upward vertical gradients in some locations and downward vertical gradients in other locations (Halpenny and others, 1952; Davidson, 1973).

Ground-water levels in the basin-fill deposits range from above land surface along perennial streams to more than $600 \mathrm{ft}$ below land surface near the mountain fronts in some basins. In nearly all basins, depth to the water table is shallowest near the location of discharge from the basin, which can range from a small area at the downstream end of the basin to essentially a line sink along the major drainage through the length of the basin. The slope of the water table typically is less than the slope of the land surface. This difference in slopes results in the greatest depths to ground water along the mountain fronts at the greatest distance from the major drainage in the basin. This depth generally occurs in the area from midway to three-quarters of the distance from the lower to the upper end of the basin, although the exact setting is dependent on the individual basin characteristics.

Water-level contours indicate the general direction of ground-water movement in a basin. The shape of the water-level contours also indicates general areas of inflow and outflow. In some basins, the water-level contours are U- or V-shaped, and in other basins, water-level contours are nearly straight lines perpendicular to the basin axis. Basins in which contours are U- or V-shaped and nearly parallel to the mountain fronts receive significant quantities of mountainfront recharge. Ground-water movement is from the basin boundary toward the basin axis, and significant discharge generally occurs along the line sink, which is the major surface drainage of the basin. Basins in which contours are relatively straight and nearly perpendicular to the mountain fronts receive little mountain-front recharge. Generally, data are not available to document the exact shape of waterlevel contours at the mountain fronts in these basins. Recharge in these areas is small and sporadic. The general shape of water-level contours in these basins may lead to the conclusion that ground-water flow may be through the entire basin from the upstream to the downstream ends with only small contributions from the lateral mountain-front areas. Results of model analyses are insensitive to the magnitude and spatial distribution of recharge used in basin simulations where recharge is small. The rate of ground-water movement in the alluvial deposits depends on the physical and hydrologic characteristics of the material and on the hydraulic gradient. Ground-water movement generally ranges from a few feet to a few hundred feet per year on the basis of information on hydraulic gradient, porosity, hydraulic conductivity, and transmissivity.

\section{PREDEVELOPMENT FLOW SYSTEM}

Prior to development of the ground-water and surface-water resources, the regional ground-water flow 
system and the individual basin systems were assumed to be in equilibrium-long-term recharge was equal to long-term discharge and no change in storage occurred. The basis for the assumption that equilibrium conditions existed lies in the absence of major humanmade impacts on the ground-water systems. Natural variations probably were occurring as long-term trends or cyclic variations over decades and centuries. These natural variations were assumed to be small compared with the impacts of humans beginning in the early part of the 20th century.

A conceptual model of the predevelopment hydrologic system of the entire area was developed as part of this study (Freethey and Anderson, 1986). The quantities of recharge and discharge and the volume of water in storage were estimated from field data, numerical modeling, and information transfer. The transfer of information was based on known similarities in physiographic setting and in lithology of the basin-fill sediments between adjacent or nearby basins.

Ground-water inflow to the basin-fill aquifers occurs primarily through three mechanisms: (1) infiltration of runoff along the major streams, (2) infiltration along the mountain fronts, and (3) underflow from adjacent basins (fig. 8). The total average annual inflow to all the basins of the study area for predevelopment conditions is estimated to have been 2.5 million acre-ft. In general, water enters an aquifer at the upstream end of a basin and along the mountain fronts, flows toward the basin center, and exits at the downstream end. The specific flow characteristics in a basin or for a group of basins are dependent on the hydrologic properties of the aquifer material and on the total annual flow through the aquifer.

The estimated quantities of inflow to the study area before development are summarized in table 1.
TABLE 1.-Estimates of water budget before development, in acrefeet per year ${ }^{1}$

Inflow:

Underflow from outside the study area---- $\quad 13,000$

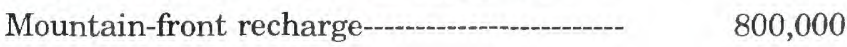

Streamflow infiltration ---_-_-_-_-_-_- $\quad 1,700,000$

Total

$2,500,000$

Outflow:

Underflow leaving the study area --------- $\quad 130,000$

Discharge to streamflow --_- $\quad 300,000$

Evapotranspiration---100,000

Total -

${ }^{1}$ All values are rounded to two significant figures.

Streamflow infiltration was about 68 percent of the total inflow. More than 80 percent of the streamflow infiltration occurred along the Colorado River; most of the remainder occurred in the central and west basins along the Salt and Gila Rivers. Net recharge from streamflow infiltration was small in the southeast and highland basins because of shallow depths to water and the general presence of perennial flow in the major streams.

The quantity of mountain-front recharge that occurs in a basin is approximately proportional to the amount of precipitation that falls on the entire basin. Mountainfront recharge was a principal inflow component in the basins in the southeast and highland groups and accounted for an estimated 25 and 55 percent, respectively, of the area-wide total. Recharge along the mountain
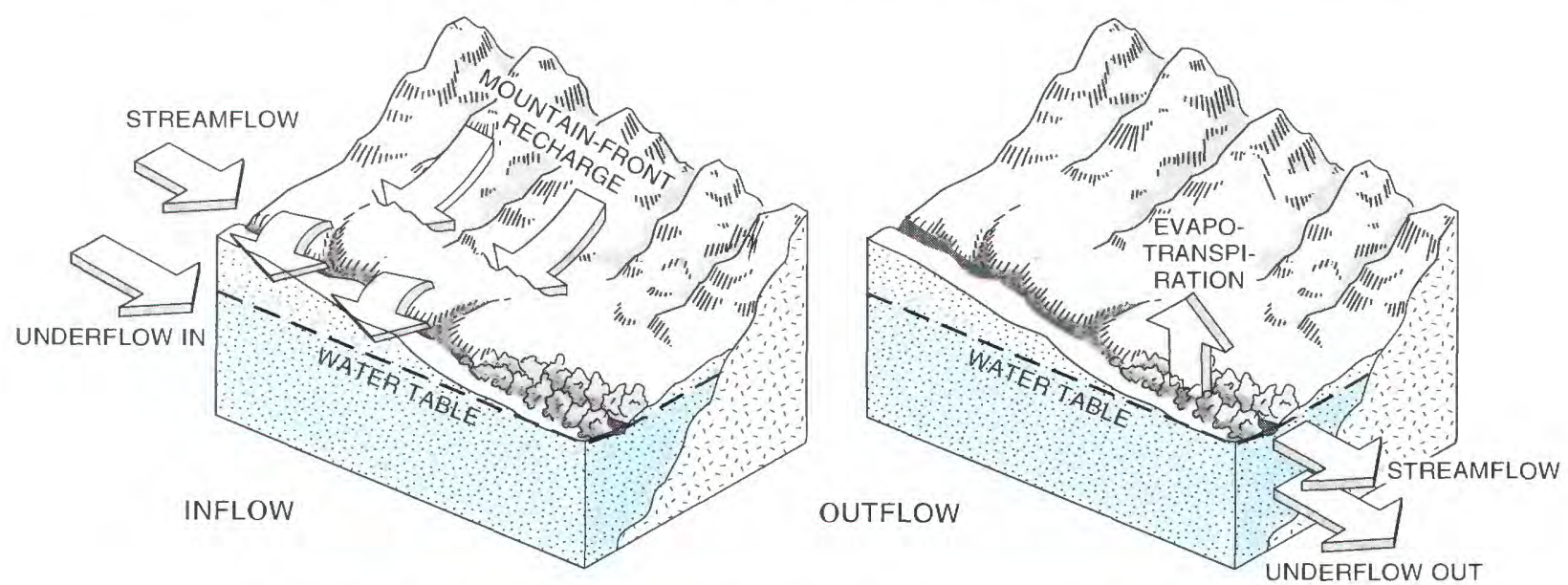

FIGURE 8.-Typical predevelopment inflow and outflow components in the alluvial basins. 
fronts was not significant in the Colorado River and west basins and was of minor significance in the central basins. Of the basins in these three groups, mountainfront recharge is largest in the Tucson basin, which is contiguous with the southeast group. Tucson basin exhibits some characteristics of the basins of the southeast group and some characteristics of the basins of the central group and could be included in either group depending on the particular factors that are being considered.

Recharge along the mountain fronts is a component of unknown magnitude in all basins but is important in steady-state and transient models of the hydrologic systems. A result of this study was the development of a relation between precipitation and mountain-front recharge. The average annual volume of mountainfront recharge was assumed to be related to average annual precipitation on the watershed. Average annual precipitation was used because data to document the quantity are readily available for entire basins. This component is used in spite of the fact that other precipitation characteristics, such as intensity, duration, magnitude, and temporal distribution, probably have a greater control on the quantity of recharge that occurs in any year. Other factors, including geology, land-surface slope, and vegetative cover, also were not considered but probably greatly influence the amount and spatial distribution of recharge.

The quantity of water potentially available for recharge is approximately equal to the precipitation minus evapotranspiration on the watershed. Part of the precipitation accounts for changes in soil moisture, which are assumed to be small over a long period. In addition, part of the precipitation leaves the basin as surface runoff, at least during periods of greater-than-average rainfall.

A regression equation was established between the average mountain-front recharge $\left(Q_{\text {rech }}\right)$ and the total annual volume of precipitation on the watershed when the precipitation $(P)$ is in excess of $8 \mathrm{in} / \mathrm{yr}$ $(P>8)$. The equation was initially based on available previous estimates of recharge in a few basins (Halpenny and others, 1952; Anderson, 1972; Freethey, 1982). By using this equation, the average annual mountain-front recharge to each basin in the study area was estimated. These estimates were then used in the water budgets of the individual basins. Adjustments were made to balance the water budgets of the individual basins and the water budget of the entire study area. After an iterative process of balancing and modifying, the resulting mountain-front recharge estimates were of similar magnitude and, with a few exceptions, appeared reasonable for basins with similar physiography and hydrology. The final equation used to estimate the mountain-front recharge from precipitation is

$$
\log Q_{\text {rech }}=-1.40+0.98 \log P,
$$

where

$$
P=\text { precipitation greater than } 8 \mathrm{in} . / \mathrm{yr} \text {. }
$$

The equation represents a means of approximating the total annual volume of mountain-front recharge to an entire basin. The regression equation is calibrated on the basis of recharge values from numerical models developed during this study (Anderson and Freethey, 1993), previous estimates of recharge in a few basins, and water budgets for the individual basins and the entire study area. No adjustments were made for variations in geology, vegetation, and other factors. Flow-model results indicate that simulated water levels are only slightly different using a uniform distribution of mountain-front recharge compared with intermittently spaced recharge (Anderson and Freethey, 1993).

Use of the average annual volume of precipitation that is greater than $8 \mathrm{in} . / \mathrm{yr}$ on the entire watershed yielded better estimates of mountain-front recharge than using the total volume of precipitation (fig. $9 A$, $B)$. The correlation index $(R)$ for the regression is 0.95 using precipitation rates greater than $8 \mathrm{in} . / \mathrm{yr}$ and is 0.85 using the total precipitation. The threshold value below which little or no recharge may occur was set arbitrarily at the precipitation level of 8 in./yr. Use of this threshold value effectively subtracts an amount of precipitation that is lost to soilmoisture deficits and evapotranspiration, especially the localized storms of short duration.

If the water budget of a basin is small, values of individual flow components also are small. Estimates of various flow components can be influenced greatly by the degree of uncertainties of the flow component. For example, the 95-percent confidence interval of the regression equation diverges rapidly when the mountainfront recharge is less than 1,000 acre-ft/yr (fig. 9B). This divergence is due to a lack of data and a high degree of uncertainty associated with a small water-budget component and small precipitation values.

Mountain-front recharge is independent of groundwater development in a basin. The only factor that could affect the quantity of mountain-front recharge is surficial alterations in the mountain areas that would result in a change in runoff. Climatic cycles affect the amount and timing of this recharge. The regression equation does not include factors such as geology, land slope, vegetation, and soil type that 
may need to be considered for any future refinement of mountain-front recharge estimates.

Ground-water outflow from the aquifers occurs through three basic mechanisms: (1) discharge to springs and streams, (2) evaporation and transpiration from the water-table zone, and (3) underflow to adjacent basins (fig. 8). Outflow occurs at the downstream end of all basins; in a few basins, outflow also occurs along a large part of the length of the major stream that drains the basin as a combination of streamflow and evapotranspiration. The dominant mechanism through which outflow occurs depends on the individual geohydrologic setting within a basin and is greatly dependent on the physical setting at the downstream end of the basin.

The dominant outflow mechanism prior to development was evapotranspiration along stream channels (table 1), which consisted of evaporation from openwater and bare-soil surfaces and transpiration by riparian vegetation. The quantity of evapotranspiration was estimated on the basis of areal extent of vegetation determined from aerial photographs taken in 1935 and empirical values for average annual evaporation and consumptive use for the various types of vegetation. Discharge along the Colorado River accounted for about 62 percent of the area-wide evapotranspiration component.

Downvalley flow from one basin to the next can occur as surface flow, as ground-water underflow, or as a combination of surface-water and ground-water flow. A surface-water component typically exists where the cross-sectional area of the aquifer is too small to transmit the total downvalley flow under the prevailing hydraulic gradient. For this study, groundwater underflow quantities were estimated with Darcy's law using the sparse information available on cross-sectional areas of flow, hydraulic gradient, and hydraulic conductivity of the alluvial material.

Discharge to streamflow in the highland basins accounted for about 91 percent of the predevelopment areawide component (table 1), with minor amounts occurring in the southeast basins ( 8 percent of the total) and west basins ( 1 percent of the total). Average discharge to streamflow was estimated on the basis of available records, including those of continuous-record gaging stations or periodic measurements of base discharge.

Ground-water underflow leaving the study area occurred in seven areas on the northwest and south

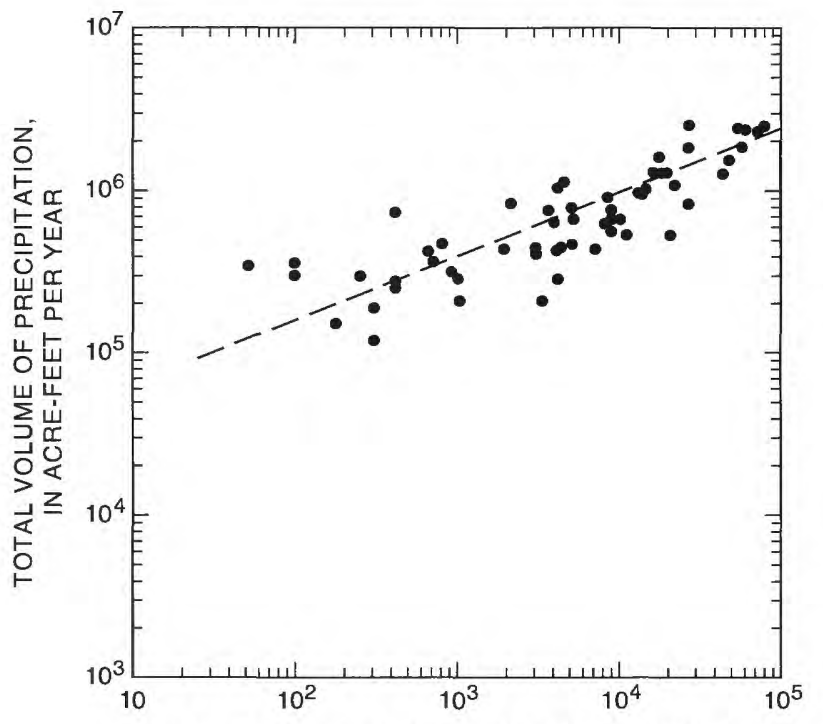

MOUNTAIN-FRONT RECHARGE, IN ACRE-FEET PER YEAR

\section{A. TOTAL PRECIPITATION ON THE BASIN}

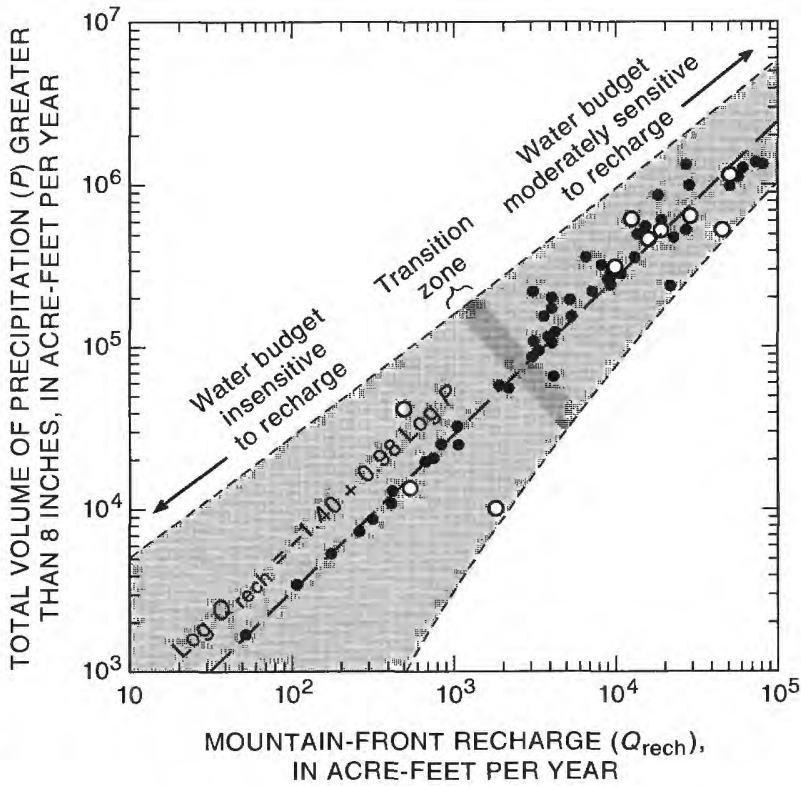

B. TOTAL PRECIPITATION GREATER THAN 8 INCHES ON THE BASIN

\section{EXPLANATION}

- MOUNTAIN-FRONT RECHARGE VALUE USED IN NUMERICAL MODEL OF BASIN-Shown only in B
- MOUNTAIN-FRONT RECHARGE VALUE USED IN REGIONAL WATER BUDGET

FIGURE 9.-Relation of estimated mountain-front recharge in a basin to total precipitation on the basin and total precipitation greater than 8 inches. 
boundaries (Anderson and others, 1992, fig. 12). The estimated outflow quantity at six of these areas ranged from 500 to 3,800 acre-ft/yr, and the total represented less than 10 percent of the total underflow out of the area. At Yuma, underflow into Mexico was estimated to be more than 110,000 acre-ft/yr where the alluvial basin is transected by the international boundary.

An estimated 900 million acre-ft of recoverable ground water was stored in the upper $1,200 \mathrm{ft}$ of alluvial deposits prior to development (Freethey and Anderson, 1986). The quantity of water stored in the alluvial-basin aquifers was hundreds of times greater than the quantity of water that flowed into and out of the basin aquifers annually. The ratio of the average annual inflow to a basin to the estimated volume of recoverable water stored in the upper $1,200 \mathrm{ft}$ of that basin ranges from about 1:5 to $1: 14,000$. The 1:5 ratio represents a basin with a small extent of basinfill deposits and therefore a small volume of water in storage, with a proportionally large annual inflow. The 1:14,000 ratio represents a basin in which annual inflow is small and the volume of water in storage is large. The typical range of the ratio for the major developed basins is from about 1:200 to 1:2,000.

Information used to estimate the volume of ground water in storage included the predevelopment watertable map (Freethey and Anderson, 1986), the depthto-bedrock map (Oppenheimer and Sumner, 1980, 1981), and available information on the textural and water-bearing character of the various units in the aquifer systems (Evans and Haimson, 1982; Freethey and others, 1986; unpublished data from files of the U.S. Geological Survey). Specific-yield values assigned to the various units of the basin fill and stream alluvium ranged from 4 to 18 percent. The various parts of the aquifer system were summed, and the volume-weighted average specific yield ranged from 5 to 16 percent for entire basins. The arithmetic average for all basins was 11 percent.

Brown (1976) estimated the volume of recoverable ground water in storage for an equivalent area to be 1,300 million acre-ft. The 900 million acre-ft derived in the Swab/RASA study is assumed to be more realistic because of the manner in which the geologic environment was discretized with variable specific-yield values assigned to individual units or parts of units on the basis of textural and water-bearing character. All other values, including area and saturated thickness, are assumed to be the same.

The quantities of recharge, discharge, and storage were estimated on the basis of field data or, in part, from previous studies. In general, for estimation of predevelopment quantities, the earliest available data were used. However, measured ground-water levels and calculated hydraulic gradients may have been affected by development that had taken place when those data were collected. The estimates are representations of the likely order of magnitude of these quantities, and inaccuracies in the estimates must be considered. Although the confidence limits of these numbers are not known, they are assumed to be about \pm 25 percent.

\section{DEVELOPMENT FLOW SYSTEM}

Development of water resources in the area began in the late 1800's, first by diversion of surface water followed by pumping of ground water. Gradual changes occurred in the regional flow system from first development through 1980 and are continuing today.

Changes in inflow components have occurred through the alteration of streamflow infiltration and by the addition of recharge from reservoir and canal seepage and from irrigated fields. No reliable estimates of the quantities or change in quantities for these components have been made on a regional basis. Additional volume within which to store infiltrated streamflow has been provided in some basins because of water-level declines, and thus streamflow infiltration probably has increased locally. In other areas, however, streamflow infiltration probably has decreased because of upstream diversions and storage of surface waters.

The other inflow components of the predevelopment water budget are assumed to be unchanged. Underflow into the study area was a minor quantity, and any changes will not significantly affect the overall budget. Inflow occurs in an area remote from development and therefore is assumed to have been constant. Mountain-front recharge is proportional to rainfall and, although probably highly variable from year to year, is assumed to have not changed as a result of development.

Additional inflow to the ground-water systems has occurred in conjunction with the spatial redistribution of surface water and ground water, mainly through the use of these waters for irrigated agriculture. Recharge originates from seepage from surface reservoirs and canals and from infiltration of excess applied irrigation water. The quantity of recharge that originates through these sources is not well known and cannot be directly measured. Quantities have been estimated through indirect means such as water-budget analyses and ground-water flow models.

Increasing evidence is available to document the occurrence of recharge from percolation of part of the 
applied irrigation water in excess of plant requirements. Areas where ground water is perched above the regional water table have been documented in at least three basins (Graf, 1980; Small, 1983; Cuff and Anderson, 1987) and anomalously high ground-water levels have been identified in another (Konieczki and English, 1979). Within the perched water zone, the aquifer material is saturated and the perched zone is separated from the regional ground-water system by an intervening unsaturated zone. The perched water zone may occur above the historical water level, indicating a change associated with development. Water in the perched zones typically is of poorer quality than the applied water because it contains the concentrated dissolved solids of the total volume of applied irrigation water, additional salts leached from the soil, and fertilizer and pesticide residue from surface applications (Schmidt, 1980). Model results also have provided evidence of recharge from excess applied irrigation water, although other factors also may be involved. Ten of twelve specific-basin flow models developed as part of this study required an additional amount of recharge in the agricultural areas to improve the match between observed and simulated heads (Anderson, 1983). The most consistent cause-and-effect relation, although not the only possibility, was that part of the applied irrigation water recharged to the regional ground-water system.

Significant changes have occurred in the outflow from most developed basins. Two major components of natural outflow-evapotranspiration and discharge to streamflow-were altered almost immediately in response to pumping. The major change in discharge, however, was the start of ground-water pumping in most basins. During 1915-80, pumpage in the study area totaled 184 million acre-ft (U.S. Geological Survey, 1982). The annual distribution of pumpage dur- ing that period is shown in figure 10. The disposition of the pumped water was predominantly consumptive use through evapotranspiration by agricultural vegetation; a part of the applied irrigation also percolated downward past the plant-root zone to become areal recharge. On the basis of the volume of sediments dewatered, approximately 50 percent of the total historical pumpage in the area represents a net depletion of ground-water storage (fig. 11). The other 50 percent was replaced through reduction of other discharges, such as streamflow and evapotranspiration in riparian zones, or increases in recharge, such as

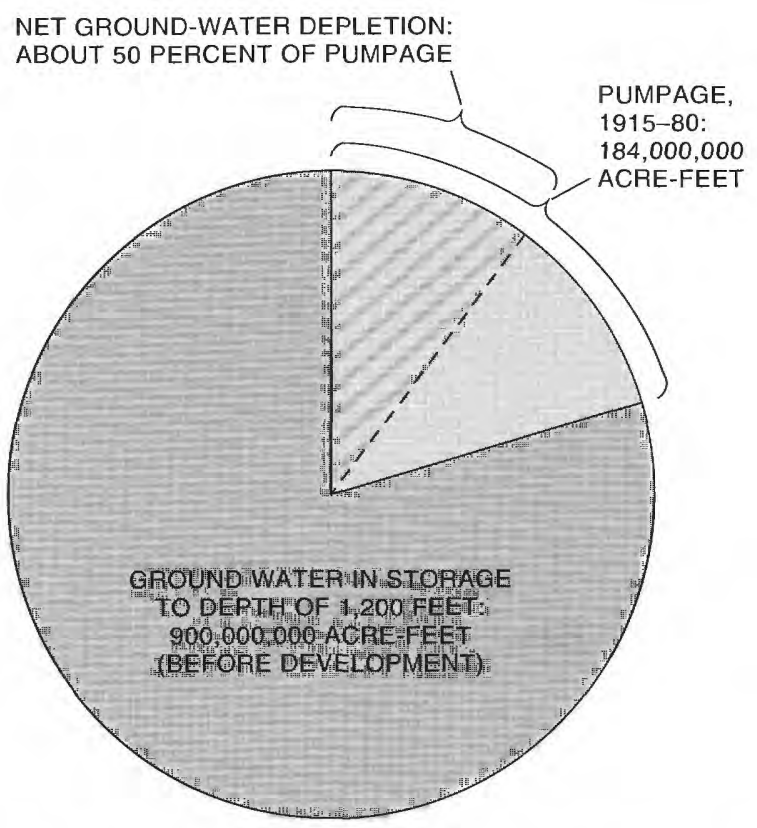

FIGURE 11.-Volume of water stored in the basin-fill aquifers to a depth of 1,200 feet below land surface, total volume pumped in 1915-80, and estimated net ground-water depletion.

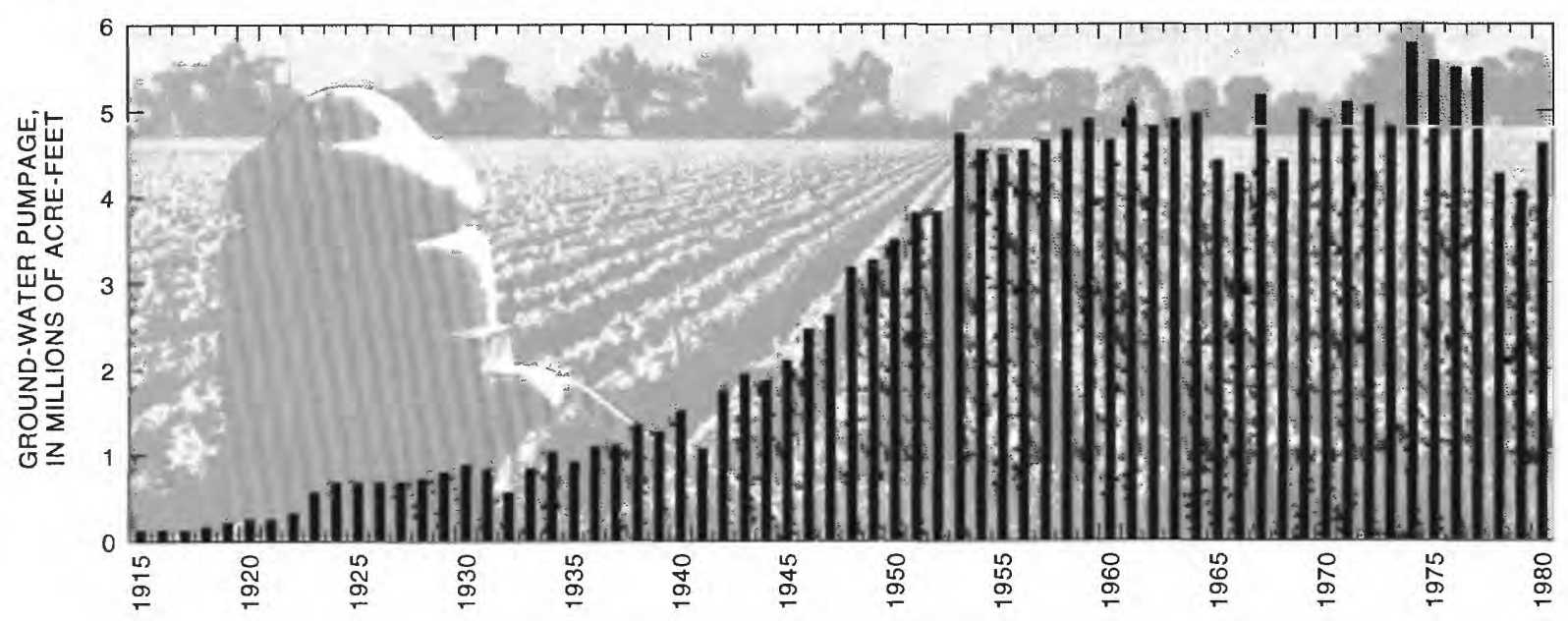

FigURE 10.-Annual ground-water pumpage, 1915-80. 
increased streamflow infiltration and return of excess irrigation water.

The regional flow system was altered as a result of development. In 1980, discharge exceeded recharge in most developed basins. Ground-water flow rates and directions have been altered and the flow direction has been reversed in parts of a few basins. The result has been capture of part or all of former discharge components. The change in the basin flow system depends on the geohydrologic setting, which is one factor incorporated into the system of basin categorization for this study. The changes associated with water-resources development, therefore, are predictable and are related to basin category.

\section{GEOCHEMISTRY}

Geochemical information was analyzed to evaluate the ground-water quality for domestic and agricultural uses and to provide an independent insight into the hydrologic flow systems. The general chemical characteristics of ground water were documented, and geochemical models were developed to evaluate the reactions and mass transfer responsible for the evolution of ground-water chemistry. These models also provided a means of estimating the chemical character of ground water in undeveloped areas. The results of the geochemistry research aspect of this study are presented by Robertson (1991).

\section{DISSOLVED SOLIDS AND OTHER CHARACTERISTICS}

The dissolved-solids and trace-element contents of ground water in most basins are at suitable levels for most purposes. Water in a few basins, however, contains excessive dissolved-solids and trace-element concentrations and presents water-quality problems. Dissolved-solids concentrations range from about 300 to $1,000 \mathrm{mg} / \mathrm{L}$ (milligrams per liter) throughout all or most of many basins but are from $1,000 \mathrm{mg} / \mathrm{L}$ to more than $10,000 \mathrm{mg} / \mathrm{L}$ in small parts of a few basins (Kister, 1973; Daniel, 1981; Thompson and others, 1984). Chemical quality of ground water in the alluvial basins varies spatially and with depth and is closely related to geology, mineralogy, structure, internal and external drainage patterns, and historical development.

The areas of lowest dissolved-solids concentrations in ground water generally are near the mountain fronts, where recharge from surface runoff occurs. Concentrations typically range from 300 to $500 \mathrm{mg} / \mathrm{L}$. Dissolved solids generally tend to increase in the downgradient direction as a result of dissolution of minerals in the sedimentary deposits. Other chemical reactions, such as ion exchange and precipitation, also may occur and thus the dissolved-solids content may vary widely. Dissolved-solids concentrations generally exceed $1,000 \mathrm{mg} / \mathrm{L}$ along part of the lower reach of the Colorado River and along the Gila River from near Safford to its mouth near Yuma; in a few places along the lower Gila River, dissolved-solids concentrations exceed $10,000 \mathrm{mg} / \mathrm{L}$ (Daniel, 1981). Dissolved solids in ground water are elevated in these areas because of dissolution of soluble minerals within the alluvium or, in a few places, concentration by evapotranspiration (Robertson, 1986a).

Generally, dissolved solids in ground water greater than $1,000 \mathrm{mg} / \mathrm{L}$ indicate that gypsum, anhydrite, halite, and other soluble salts are present in the basin-fill aquifers. In an 80-square-mile area that includes the Willcox Playa in southeastern Arizona, ground water contains from 1,000 to as much as $43,000 \mathrm{mg} / \mathrm{L}$ of dissolved solids, a result of internal surface-water drainage and ground-water discharge unique to the playa. Other localized areas where ground water contains more than $1,000 \mathrm{mg} / \mathrm{L}$ of dissolved solids are in the Benson, Douglas, Tucson, Eloy, Stanfield, Safford, and Waterman Wash basins; in Verde, McMullen, and east and west Salt River Valleys; in Ranegras Plain; and along the Colorado and lower Gila Rivers (Thompson and others, 1984; Robertson, 1990). Most of these areas are of small areal extent and probably reflect the dissolution of disseminated evaporites from within the aquifer material. Depth and producing interval are not known for all the wells that were sampled, but wellconstruction characteristics may influence dissolvedsolids concentrations measured in water samples.

Dissolved-solids concentrations in some basins increase with depth in the upper $2,000 \mathrm{ft}$ and in other basins decrease with depth. No statistically significant trend can be demonstrated for the entire study area. In most basins, however, concentrations of magnesium, bicarbonate, and silica decrease with depth, while $\mathrm{pH}$, temperature, and concentrations of most trace elements increase with depth.

The temperature of ground water generally ranges between $15^{\circ} \mathrm{C}$ and $30^{\circ} \mathrm{C}$ in recharge areas and increases to as high as $45^{\circ} \mathrm{C}$ near discharge areas. The $\mathrm{pH}$ values of ground water in recharge areas generally are near neutral but increase in downgradient and discharge areas to values as high as 9.5. Dissolved oxygen is near saturation in ground water in recharge areas and typically decreases to 50 to 80 percent of saturation near discharge areas (Robertson, 1991). 


\section{GROUND-WATER CHEMISTRY TYPES}

The chemistry of water in the basin-fill aquifers can be characterized by type on the basis of the relative concentrations of dissolved cations and anions. General patterns exist in the distribution of water types. The mineral composition of the rocks of the mountains and the unsaturated zone and the rock-water reactions influence the chemical type of ground water.

Calcium bicarbonate or calcium sodium bicarbonate type ground water is prevalent near the mountain-front recharge areas of most basin groups. The ground water evolves to a sodium mixed-anion type near the center or near the outlet of some basins or, as dissolved solids increase, to a sodium chloride or sodium calcium chloride sulfate type. Water that contains dissolved-solids concentrations of $500 \mathrm{mg} / \mathrm{L}$ or less is a sodium mixed-anion type. Ground water is a sodium chloride type in the Willcox Playa and in the east and west parts of the Salt River Valley. In areas where dissolved-solids concentrations exceed about $1,000 \mathrm{mg} / \mathrm{L}$, such as along the Gila River and the Colorado River, ground water is predominantly a sodium chloride or sodium calcium sulfate type. Ground water in the alluvial aquifers of the basins in the highland group is mainly a calcium bicarbonate or calcium magnesium bicarbonate type, particularly along the many streams. A calcium sodium bicarbonate or sodium calcium bicarbonate type water also occurs in parts of the southeast basins where recharge occurs along the valley floors.

\section{TRACE ELEMENTS}

In several basins, ground water contains concentrations of trace elements that exceed standards for public supply and certain agricultural uses. Fluoride, barium, chromium, arsenic, nitrate, mercury, lead, and boron are known to present environmental problems in some areas where concentrations exceed the maximum contaminant level (MCL) established by the U.S. Environmental Protection Agency (1977) for drinking water. The sources of these trace elements are the basin-fill sediments, which were derived from igneous, metamorphic, and sedimentary rocks of the surrounding mountains. In general, trace elements occur in concentrations below the detection level in the zones of mountain-front recharge, where a large percentage of the ground water enters the aquifer system. Concentrations tend to increase in the downgradient direction.

In many basins, ground water contains fluoride concentrations that exceed the MCL. The ingestion of water containing small concentrations of fluoride is beneficial in the prevention of tooth decay, but large concentrations can result in mottling of teeth. Concentrations of fluoride greater than $6 \mathrm{mg} / \mathrm{L}$ are closely related to the occurrence of rhyolitic and andesitic volcanic rocks, which appear to serve as a major source of fluoride. Where granite and gneiss are the dominant rock types, fluoride concentrations generally are less than $1 \mathrm{mg} / \mathrm{L}$ but in places may exceed $3 \mathrm{mg} / \mathrm{L}$.

Fluoride concentrations exceed $2 \mathrm{mg} / \mathrm{L}$ in small parts of many basins and exceed $5 \mathrm{mg} / \mathrm{L}$ in parts of the confined basin-fill aquifers of the Benson, lower San Pedro, and Safford basins and San Simon Valley. Concentrations also exceed $5 \mathrm{mg} / \mathrm{L}$ in large parts of Ranegras Plain; lower Hassayampa, Waterman Wash, and Gila Bend basins; and the Sentinel Plain area west of the Gila Bend basin. The largest fluoride concentration, which was in excess of $200 \mathrm{mg} / \mathrm{L}$, is in the Willcox Playa and is a result of evaporative concentration (Robertson and Garrett, 1986).

\section{GEOCHEMICAL MODELS}

Geochemical models can be used to simulate chemical reactions that occur between water and rock material of the aquifer as the water moves along a flow path through the hydrologic system. The purpose of geochemical modeling is to quantify the natural geochemical processes that control the chemistry of ground water. Data used in the modeling include the chemical composition of water in the recharge area, mineralogy of the rock matrix that makes up the aquifer, and chemical composition of ground water at one or more points along a flow path or at a point of discharge from the basin. These models provide information to evaluate reactions occurring in the system and an independent means of analyzing the hydrologic flow system. Geochemical models were developed for six basins (fig. 6). The model results were used to verify an existing conceptual model of the flow system and provided valuable insight into the relative significance and magnitude of various flow components. Robertson (1991) grouped the basins of the study area into two types-open systems and closed systems-on the basis of the chemical evolution as derived from geochemical-model results.

Open systems are those in which additional water and gases may be added to ground water along the flow path within a basin. These conditions prevail where precipitation is greatest, where shallow ground water occurs, and where no extensive fine-grained unit overlies the principal basin-fill aquifer. These conditions occur in the highland basin group, in the water-table 
aquifers of the southeast basin group, and in parts of the central basin group. Specific basins of this type include Willcox, Douglas, upper San Pedro, and Tucson basins and Avra and Altar Valleys. Open systems occur in the shallow aquifers that include stream alluvium along the Gila, Salt, and San Pedro Rivers and San Simon Creek and in the Big and Little Chino Valleys, Agua Fria basin, and other stream-alluvium aquifers of the highland basin group. Because of the contributory effects of additional water and gases along the general flow path, geochemical modeling and predictability of open systems are not as reliable as those of closed systems unless large dissolved-solids concentrations are present. Large dissolved-solids concentrations occur mainly from dissolution of halite and gypsum, and these reactions can be predicted.

Closed systems are those that do not receive additional recharge or gases along the flow path. Closedsystem conditions exist where depths to ground water are great and recharge occurs only along the mountain fronts. These conditions also exist in confined-aquifer systems or where leaky confined conditions occur in which hydraulic head increases with increasing depth. This type of system occurs in the west basin group, in most of the central basins, and in the deep confined aquifers of lower San Pedro, Benson, San Bernardino, and Safford basins and Little Chino and San Simon Valleys. In closed systems, the chemistry of ground water is determined by the reactions of the initial recharge water with the minerals present in the aquifer matrix as the water moves downgradient. In such a system, the concentrations of major dissolved ions and the occurrence of some trace elements can be reliably predicted.

The results of geochemical modeling indicate that the processes that control ground-water chemistry include weathering of plagioclase, potassium feldspar, and ferromagnesian minerals; formation of montmorillonite; precipitation of calcite and probably of silica; and, in some basins, ion exchange (Robertson, 1989a). On the basis of these reactions and the associated mass transfer, information transfer was tested and successfully applied in some basins and is a potentially powerful tool for assessment of water quality and geochemistry in undeveloped basins.

\section{WATER-RESOURCES DEVELOPMENT}

\section{HISTORY OF DEVELOPMENT}

Archeological evidence indicates that development of water resources in part of the area began as early as 300 B.C. when the Hohokam Indian culture devel- oped an agricultural-based society and diverted waters of the Salt and Gila Rivers through a network of canals to irrigate the flat land adjacent to the rivers (Haury, 1976; Lister and Lister, 1983). In the middle to late 1800 's, as part of the westward migration, early settlers used available surface waters to support agricultural development. Because of the sporadic nature of streamflow in the area, ground-water resources were soon developed to supplement the highly variable surface-water supply. By 1889 , the total irrigated acreage in Arizona was nearly 66,000 acres (Davis, 1897, p. 54).

The first wells in the area generally were shallow, hand-dug wells of large diameter. In the late 1800's and early 1900's, most wells were along the flood plain of perennial streams. Because centrifugal pumps were the type commonly available at that time for lifting large quantities of water, pumping for irrigation generally was in areas of shallow ground water. In 1915, an estimated 123,000 acre-ft of ground water was pumped from wells (U.S. Geological Survey, 1982), mainly near Florence and Coolidge in the Eloy basin and near Phoenix in the Salt River Valley.

Development began at different times in various basins. As early as 1920, development was mostly in the east and west Salt River Valley, Eloy basin, and Stanfield basin (fig. 1). In 1940, nearly 1 million acre-ft of ground water was withdrawn in the east and west Salt River Valley; another 0.5 million acre$\mathrm{ft}$ was withdrawn in Eloy, Stanfield, Tucson, and Yuma basins. The remainder of the basins were undeveloped or slightly developed until after 1940 .

Several factors greatly affected the use and development of the ground-water resources. Development of the deep-well turbine pump in the 1930's increased the accessibility of ground water. Availability of cheap electric power aided in the growth of groundwater use. Increased demands for agricultural products linked with technological advances resulted in vast increases in pumpage during and after the 1930's. During World War II, the most substantial increase was in the acreage of cotton grown in support of the war effort.

Since World War II, the basin-fill aquifer systems have been increasingly stressed to support agricultural activities. The estimated pumpage in 1942 was about 1.7 million acre-ft (U.S. Geological Survey, 1982; fig. 10, this report) and was the beginning of a period of rapid growth. By 1952, the estimated pumpage had more than doubled to 3.8 million acre$\mathrm{ft}$, and by 1962 pumpage was about 4.8 million acre$\mathrm{ft}$. During 1950-80, average pumpage was estimated to be 4.8 million acre-ft/yr, which is nearly twice the 
average annual recharge into the area. The volume of pumpage in a basin in excess of recharge represents withdrawal from storage. Pumpage is estimated to range from about 2 to more than 200 times greater than the recharge rate in individual basins.

Total irrigated acreage in the study area in 1980 was about 1.2 million acres; the major crop was cotton, which accounted for about 50 percent of total irrigated acreage. Other extensively grown crops were grains and hay, which together accounted for 42 percent of the irrigated acreage. In 1980, crop production from irrigated agriculture accounted for about 7 percent of the area's economic income (Valley National Bank, 1983). Agriculture accounted for 88 percent of the area's total water use in 1980 (White and Anderson, 1985; Anderson and White, 1986).

\section{EFFECTS OF DEVELOPMENT}

The effects of development of water resources on the hydrologic systems can be related to basin category. The dominant effect, which has occurred in nearly all basins, is decline of water levels and the associated depletion of aquifer storage, although water levels have risen in some basins along the Colorado River as a result of irrigation. This effect is directly measurable through monitoring of water levels. Other attendant effects include alteration of the natural flow system, which potentially can result in significant alterations of the natural environment; changes in water quality; and the occurrence of land subsidence and formation of earth fissures.

Large quantities of ground water are stored in the interstices of alluvial sediments that fill the basins. This water accumulated over thousands of years. Development has resulted in removal of part of that water and, where pumping exceeds the natural rate of recharge, overdraft or mining of ground water has occurred. Declining water levels and depletion of aquifer storage are one effect of development and, for a unit volume of water pumped from an aquifer, part or all of that volume can represent a net removal from storage. The aquifer response depends on the hydrologic setting-primarily the potential for capturing additional recharge or diverting natural discharge. The magnitude of water-level declines also depends on the geologic setting-specifically, lithology and texture of the basin-fill deposits. For a unit volume of pumpage, water levels decline more near the center of pumpage in a setting of fine to very fine grained sediment than in a setting of coarse-grained sediment.

From the time development began through 1980, the maximum water-level decline in the area was more than $450 \mathrm{ft}$ in Stanfield basin; during 1923-77, more than $420 \mathrm{ft}$ of decline occurred southeast of Chandler in the east Salt River Valley (Laney and others, 1978). Declines of more than $200 \mathrm{ft}$ occurred by 1980 in Harquahala Plain, McMullen Valley, Willcox basin, San Simon Valley, Eloy basin, and throughout large areas of the east and west Salt River Valley (fig. 1). The approximate extent and magnitude of water-level declines in the study area from the time development began through about 1980 are documented in figure 12 (Anderson and others, 1992, pl. 3).

The greatest alteration of a ground-water flow system occurred in Stanfield basin in the central part of the study area. Ground-water flow through the area in 1923 was from the southeast toward the northwest (fig. 13A). The gradient of the water table ranged from about 5 to $20 \mathrm{ft} / \mathrm{mi}$ (Anderson, 1968). By 1977, more than $450 \mathrm{ft}$ of water-level decline had occurred and ground-water flow was approximately radial toward a cone of depression centered on the west side of the basin (fig. 13B). The gradient of the water table was as great as $100 \mathrm{ft} / \mathrm{mi}$ toward the center of the cone of depression (Konieczki and English, 1979), and the direction of flow in the northern part of the basin changed from northwest in 1923 to south or southwest by $1976-77$.

Rates of water-level decline have ranged from less than $1 \mathrm{ft} / \mathrm{yr}$ in areas of slight development to nearly $24 \mathrm{ft} / \mathrm{yr}$ as measured at one well in Stanfield basin in the 1950's (Anderson and others, 1992, fig. 26A). Decline rates generally have been less since the late 1960 's than they were during the 1950 's to mid1960 's. The most important factor is decreased pumpage in areas of maximum decline. This decrease in pumpage probably is related to increased cost of power compounded by increased power requirements per unit of water pumped because of water-level declines. Increased capital investment needed for deepening wells and installing equipment of greater lift capacity also could be a related influence. Other factors are increased recharge from infiltration of excess applied irrigation water and drainage of water from fine-grained units as a result of inelastic compaction. Inelastic compaction results in a permanent loss of ground-water storage. Increased irrigation efficiency and conversion to crops that require less water could be locally significant but are not the cause of the general, widespread trend of decreased rate of waterlevel decline.

The volume of ground-water depletion in developed basins has ranged from less than 1 percent to as much as 15 percent of the estimated volume that was in storage within $1,200 \mathrm{ft}$ below land surface prior to development. A small increase in ground-water 


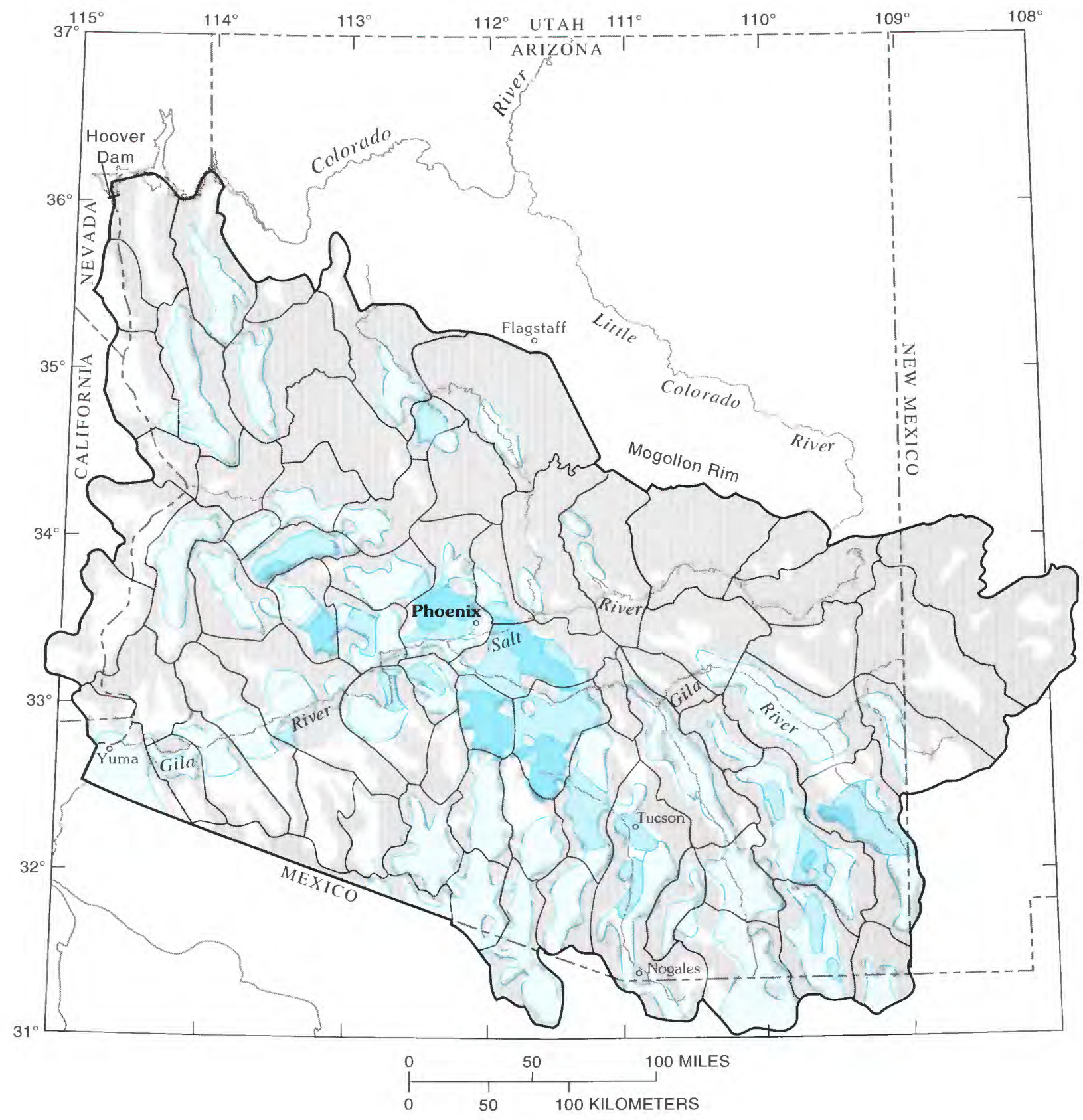

EXPLANATION
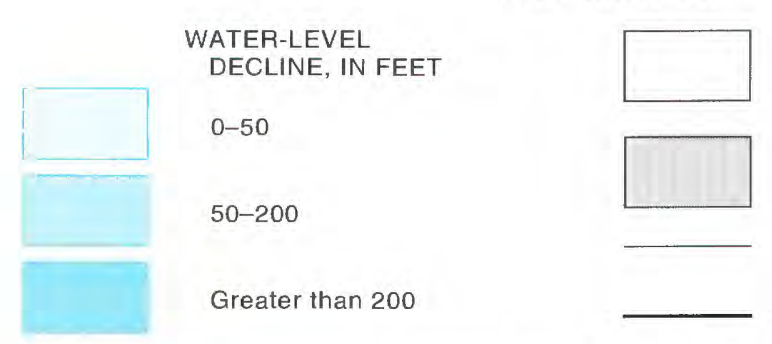
ALLUVIAL DEPOSITS-Locally may include
evaporite deposits and volcanic rocks

BEDROCK OF THE MOUNTAINS

BASIN BOUNDARY

FIGURE 12.-Areas of water-level decline from the beginning of development through 1980. 


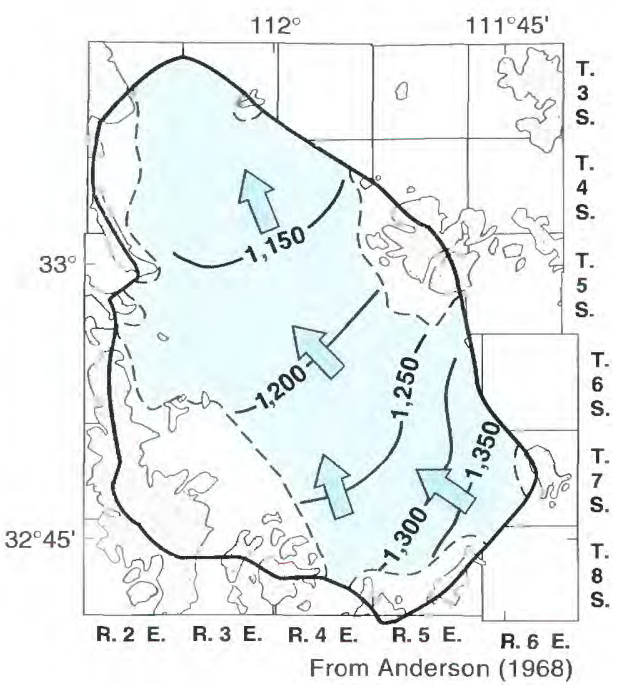

A. 1923

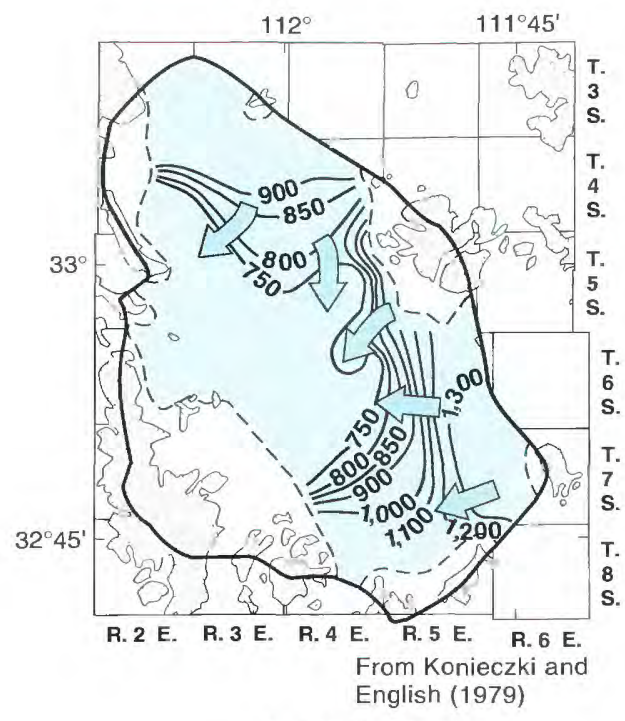

B. $1976-77$

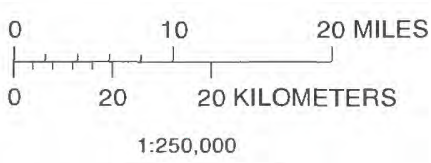

EXPLANATION

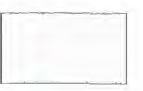

BEDROCK OF THE MOUNTAINS

APPROXIMATE EXTENT OF MAIN

WATER-BEARING UNIT

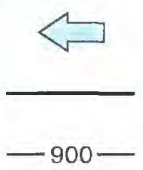

DIRECTION OF GROUND-WATER FLOW BOUNDARY OF STANFIELD BASIN

WATER-TABLE CONTOUR-Shows altitude of water table. Contour interval 50 and 100 feet. Datum is sea level

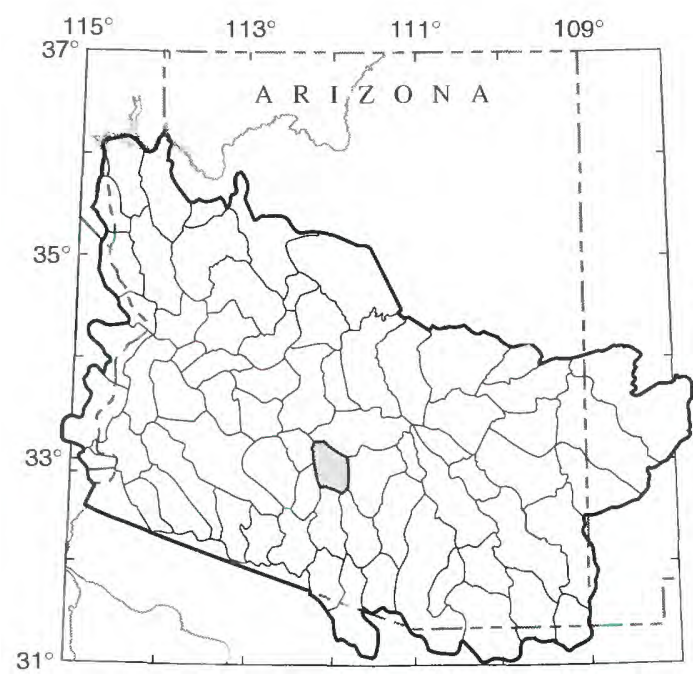

INDEX MAP SHOWING LOCATION OF STANFIELD BASIN (SHADED) IN Swab/RASA STUDY AREA

$$
\left.\right|_{0} ^{0} 50 \text { KILOMETERS }
$$

FIGURE 13.-Ground-water flow system in Stanfield basin, 1923 and 1976-77. 
storage has occurred in several basins along the Colorado River following several feet of water-level rise under irrigated fields.

As ground water is withdrawn from storage and water levels decline, additional system adjustments also occur. Withdrawal and consumptive use in a basin have resulted in capture of all or part of former discharges and has increased recharge. Specifically, evapotranspiration and underflow have decreased in a number of basins. Recharge from infiltration along major streams generally has increased, but the areas where increases have occurred are only along those streams where a significant part of the base flow has been diverted, either by upstream withdrawal or by ground-water pumping. In some instances, underflow into a basin has been increased, although this depends greatly on development in the upstream basin. Once development begins, the trend is for outflow to decrease because of partial capture by ground-water pumping. The overall result can be a change in environment, particularly in the riparian zone. A streamflow regimen change from perennial to intermittent will result from upstream diversion and groundwater pumping and is the most readily observed effect. This change has occurred throughout the reach of the Salt River from Granite Reef Diversion Dam to near the confluence of the Salt and Gila Rivers west of Phoenix. Extensive reaches of the Gila River between Safford and Yuma have undergone major changes in flow regime because of upstream diversion and storage. Near Tucson, selected reaches of the Santa Cruz River and Tanque Verde and Rillito Creeks no longer contain perennial flow because of extensive ground-water development and associated lowering of the water table.

Riparian habitat has been severely altered as ground-water levels are drawn down below the root zone of the riparian vegetation. Extensive mesquite bosques have died because of this change in the hydrologic system. Instances where this has occurred are documented along the Gila River near Coolidge in Eloy basin, west and southwest of Tucson along the Santa Cruz River, and along the Salt River east of Phoenix. Decreases in acreage of riparian vegetation and annual consumptive use from 1952 to 1967 were estimated to be 120,400 acres and 435,000 acre$\mathrm{ft}$, respectively, as a result of ground-water development (Arizona Water Commission, 1975, p. 107).

In some areas, effects of ground-water mining have been lessened by the capture of additional recharge or natural discharge. Opportunities for this capture to occur generally were of minor significance or insignificant in the west basins, and were moderately significant in the central basins, especially after flows of the major rivers-the Gila, Salt, Verde, and Agua Fria-were diverted or stored in upstream reservoirs. Opportunities for significant capture existed in the southeast and highland basins. Almost total capture has occurred in Willcox and Douglas basins. In all other basins of the southeast and highland groups, natural discharge by evapotranspiration and streamflow continues, although reductions in these flow components have occurred. The hydrology of the Colorado River basins is dominated by surface flow in the river, which acts as a source or sink for water in the basin-fill aquifers. Capture of discharge is affected by the rapid establishment of a new equilibrium condition following an increase or decrease in ground-water pumping-nearly all the change in the flow system involves the quantity of ground-water flow to or infiltration from the river.

Water-level declines reflect the change from saturated to unsaturated conditions in the aquifer material and are accompanied by increases in the intergranular loading in the sediment because of the removal of the buoyant effect of the water. The result is slight elastic compaction of the coarse-grained aquifer material and greater inelastic compaction in the fine-grained sediment owing to reduction of the volume of pore space. The degree of inelastic compaction is related to thickness and inelastic compressibility of the fine-grained sediment contained in the aquifer system. In basins where the aquifer system includes thick sequences of compressible fine-grained sediment, land subsidence can occur in response to dewatering of the sediment or decline of artesian head in the deeper, confined parts of the system. Because the basins are surrounded and underlain at variable depths by consolidated rocks and the subsurface lithology is not uniform, vertical subsidence does not occur uniformly over large areas. Tensional stresses are created near the perimeter of areas of large water-level decline and land subsidence (Laney and others, 1978). The result is the occurrence of earth fissures in these areas of greatest tensional stress.

Land subsidence and the occurrence of earth fissures, which are related to ground-water withdrawal and associated water-level declines, have been documented in highly developed parts of central Arizona (Schumann and Poland, 1970). Near Eloy, subsidence measured at one bench mark during 1952-77 was $12.5 \mathrm{ft}$ (Laney and others, 1978). In Eloy and Stanfield basins, more than $120 \mathrm{mi}^{2}$ are known to have subsided at least $7 \mathrm{ft}$ during 1952-77 (Laney and others, 1978), and more than $1,000 \mathrm{mi}^{2}$ are known to have subsided at least $3 \mathrm{ft}$ (Poland, 1981). During 1937-74, more than $5 \mathrm{ft}$ of subsidence was documented at one bench mark about $8 \mathrm{mi}$ northwest of Willcox, and $4.6 \mathrm{ft}$ of subsidence was measured dur- 
ing 1952-74 near Bowie in San Simon Valley (Holzer, 1980). Earth fissures have been mapped at various times since they were noted in 1927 (Leonard, 1929), and a recent study (Schumann and Genualdi, 1986) documented earth fissures in southern Arizona. Fissures start as narrow linear features and increase in width and length as additional ground movement and erosion occur. Vertical offset may occur across the earth fissure. A fissure system near Eloy (fig. 14) is more than $8 \mathrm{mi}$ long and has had vertical offset of about $3 \mathrm{ft}$ (Winikka and Wold, 1977).

The principal effect of subsidence on basin hydrology is the permanent loss of aquifer storage. The volume of lost storage in the aquifer is equal to the volume of land subsidence, which in the Eloy basin alone is nearly $1 \mathrm{mi}^{3}$ or about 3.4 million acre-ft of water. Generally, inelastic compaction of fine-grained sediment continues for a long time following a reduction in pumping. On the basis of one-dimensional compaction modeling, Epstein (1987) estimated that the sediment near Eloy would continue to compact for more than 300 years even if withdrawals ceased. Expulsion of additional water that does not discharge through gravity drainage accompanies compaction of the fine-grained sediment. This water of compaction contributes to the decreased rate of water-level decline observed since the late 1960's.

The geohydrologic environment in the alluvial basins is conducive to the occurrence of land subsidence. Because of the common presence of extensive finegrained sediment in the center of most basins, groundwater depletion and the attendant increase in applied system stress will result in inelastic compaction of the sediment after a threshold value of water-level decline is exceeded. This threshold value varies as a function of geologic environment but is typically on the order of 150-200 ft. Land subsidence is a problem in several basins and is a potential problem in all basins where ground-water withdrawals will result in water-level declines greater than about $150 \mathrm{ft}$.

Development of techniques to simulate land subsidence has been ongoing as a followup to the current RASA study. A compaction simulation program has been developed, tested, and documented as part of that followup study (Leake and Prudic, 1988). Simulation and model calibration were conducted using data from the Eloy basin and have proved successful. The ability to simulate and predict subsidence will become

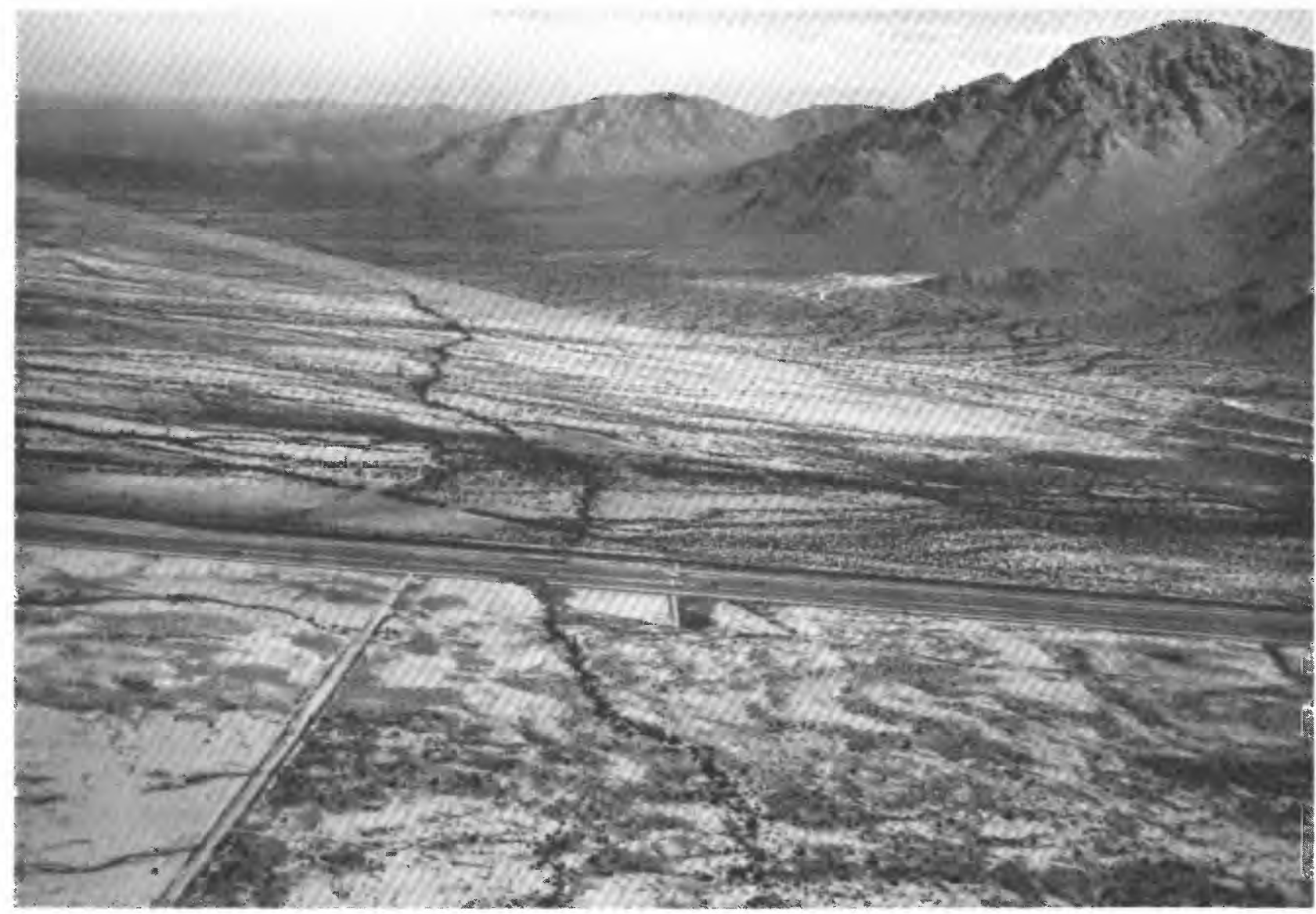

FIGURE 14.-Earth-fissure system more than 8 miles long, near Eloy, Arizona. 
increasingly important as an adjunct to successful management of ground water. Additional work is needed to monitor actual land subsidence and earth fissuring in the most extensively developed basins and to collect detailed information on the basin lithology in order that subsidence can be included as an integral part of future simulation studies.

The physical effects of land subsidence and earth fissuring are of economic importance in developed basins. Changes in land-surface slope, especially along the outer area of subsidence, have resulted in damage to irrigation systems, sewer systems, pipelines, streets, roads, interstate highways, and railroads. A common problem caused by compaction is the collapse of well casings. More extensive flooding from surface runoff may result from changes in the channel slope because of subsidence. In a few places, effects of land subsidence and earth fissuring have necessitated rerouting the Central Arizona Project canal, which is used to import water from the Colorado River to the central part of Arizona. Monitoring and investigations of subsidence are essential to develop methods of predicting the occurrence and magnitude of subsidence and earth fissures.

A general trend exists in most basins in which the sediments are more consolidated and more strongly cemented with increasing depth. The result generally is decreased well yield with depth. Ground-water quality also is variable with depth in many basins and reflects the variable composition of basin-fill sediment. In areas where evaporites are present, dissolved solids in ground water may increase severalfold in the downgradient direction and water type likely will change from a calcium bicarbonate or sodium bicarbonate type to a sodium chloride or sodium calcium sulfate chloride type.

A major effect of development on water quality is associated with the migration of chemicals from land surface to the water table with accompanying adverse effect on the quality of ground-water supplies. Chemical contaminants have been detected in the unsaturated zone, in perched water zones, and in the saturated zone. The chemicals include a broad array of agricultural fertilizers and pesticides, industrial solvents and trace metals, and chemicals associated with municipal and industrial waste. Both nonpoint and point sources have contributed to ground-water contamination. The common means for chemicals to reach the water table has been by leaching through the unsaturated zone following surface application or shallow burial. Contamination has occurred by rapid movement of chemicals through well boreholes and through preferential flow paths such ás animal burrows, plant-root holes, small vertical cracks, or more permeable zones that occur naturally in the alluvial deposits. Earth fissures also represent a means of solutes reaching the water table with little or no attenuation.

The extent of degradation of the ground-water quality attributable to the percolation of chemicals from the land surface depends on the volume and rate of flow through the unsaturated zone. Few data are available to document the rate of flow. In undeveloped basins, moisture content in the thick unsaturated zones is small. Therefore, the thickness of unsaturated material and the difference between moisture content of the sediment prior to development and at field capacity will determine the amount of infiltration necessary and the time required before recharge will occur at the regional water table.

Stream alluvium along the major surface drainages in the area serves as efficient natural recharge areas. The physical nature of the alluvial material has aided certain adverse effects of development. The unconsolidated, surficial materials are easily mined, and the well-sorted sand and gravel fulfills a broad range of construction-related uses. Sand- and gravelmining operations have affected the rate and volume of natural sediment transport in streams during major runoff events. In addition, the large open pits that result from gravel mining are attractive locations to bury municipal and industrial wastes. Liquids readily move through the stream alluvium, and contamination of ground water has occurred because leachate has drained from these waste-disposal sites. Chemicals in the landfills also may be dissolved and flushed through the material by water that infiltrates during flood events. Present and future activities in these major recharge areas may have a significant effect on regional water quality.

\section{CONSIDERATIONS FOR FUTURE DEVELOPMENT}

The responses of the ground-water systems to development have been documented and follow a systematic pattern related to the geohydrologic characteristics of the five basin categories defined previously. The general relation between increased pumpage and changes in the principal water-budget components for each basin category is shown in figure 15.

The relation between magnitude of pumpage and net volume of water withdrawn from storage is illustrated in figure $15 \mathrm{~A}$. An extreme condition occurs in the west basins, where pumpage of almost any magnitude will result in storage depletion; the relation is virtually linear. The other extreme is represented by the Colorado River basins. Only a small volume of water can be withdrawn from aquifer storage as 
A. VOLUME OF GROUND WATER FROM STORAGE

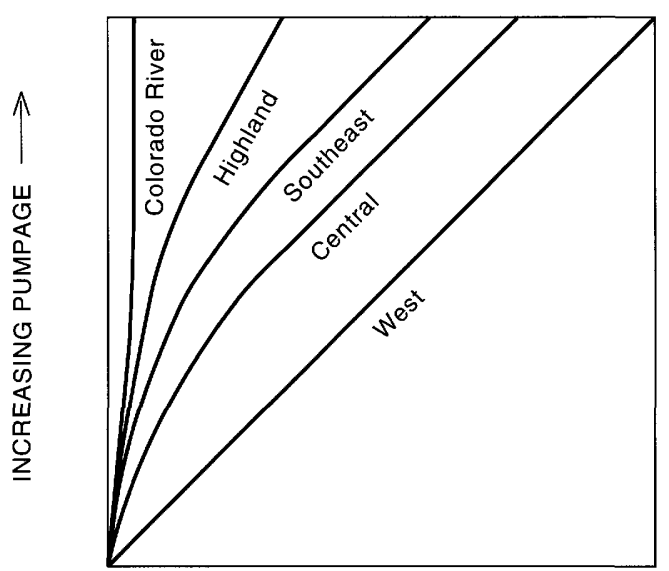

INCREASING VOLUME REMOVED FROM STORAGE $\longrightarrow$

B. AQUIFER DISCHARGE THROUGH EVAPOTRANSPIRATION

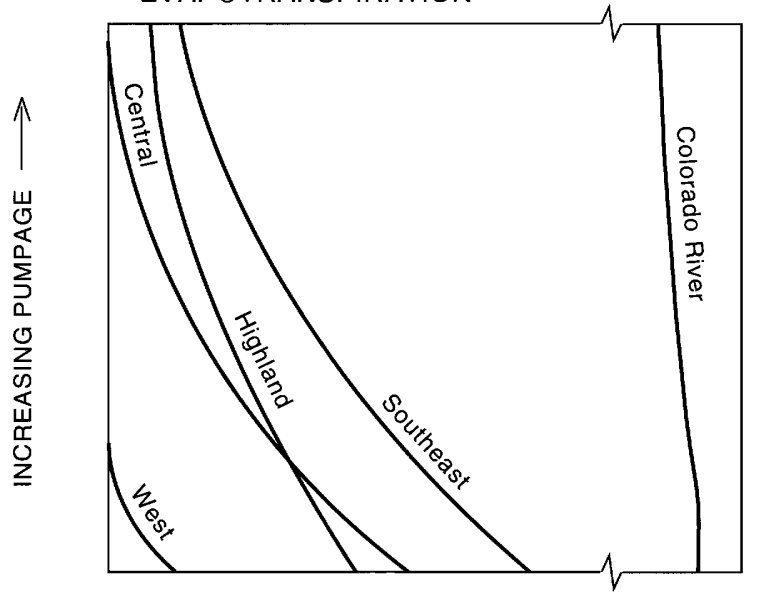

INCREASING DISCHARGE THROUGH EVAPOTRANSPIRATION $\longrightarrow$

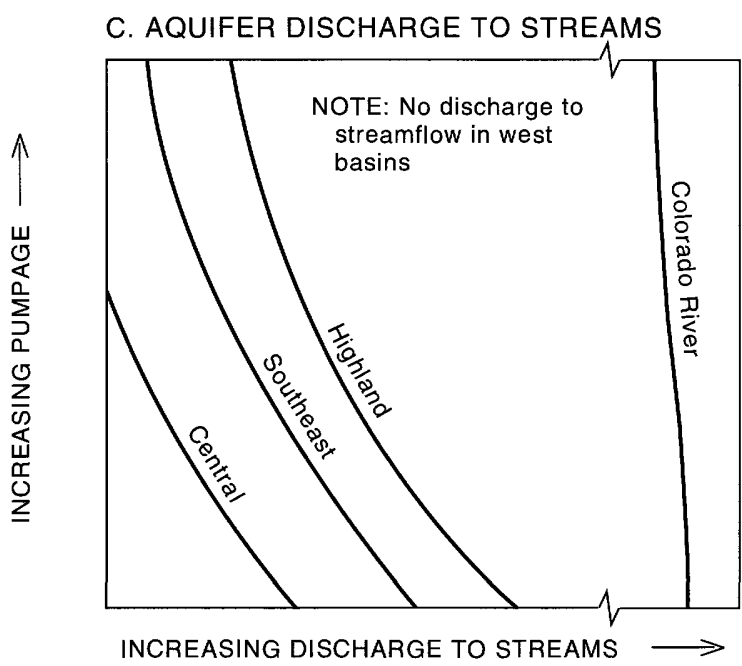

FIGURE 15.-Generalized relation between increasing pumpage and changes in water-budget components. pumpage increases from aquifers of this basin group as long as surface water in the Colorado River is available to infiltrate into the ground-water system and replace the withdrawn water. When water is pumped from a well, the gradient from the river toward the well is increased and additional infiltration of river water results. The typical response of the other basin groups range between these two extremes, depending partly on the rate at which capture of other discharge and recharge components occurs.

Evapotranspiration by native vegetation typically decreases as nearby pumping increases and water levels decline. The general system response for each basin group is illustrated in figure $15 B$. A small change occurs in basins of the Colorado River group, and conversely all natural discharge by evapotranspiration is captured soon after pumping is initiated in the basins of the west group. Similarly, changes in discharge to streamflow in response to pumping are illustrated in figure $15 C$. The Colorado River group is again representative of one extreme, indicating only a small change in aquifer discharge to streams. Because no stream base flow generally occurred in the west basins, except for what occurred in the lower Gila River prior to development, no change can occur in the typical west basin. In basins of the central group, the small quantity of water that discharged to streams was rapidly and totally captured following the start of pumping. These two system responsesdecreases in natural evapotranspiration and discharge to streamflow-are functionally related. Ground-water development near the stream flood plain eventually will result in capture of part or all of these flow components, which will alter the natural riparian environment.

Development through 1980 depleted from less than 1 to about 15 percent of ground water in storage in the alluvial-basin aquifers; a much larger volume remains in storage. The degree and rate at which further depletion occurs will be controlled by economics. As in the past several decades, future growth probably will occur at the expense of agriculture.

Although the magnitude of the available groundwater supply will not be reduced as contamination occurs, the expense of treating contaminated waters may serve that effect. Additional studies and monitoring are needed to determine the effects of areal application of chemicals and burial of wastes. Alternatives to present disposal techniques need to be found. Various conservation and public-education campaigns presently are being pursued.

The Arizona Groundwater Management Act of 1980, which was enacted to reduce the long-term 
overdevelopment of ground-water resources, will significantly affect future development. As a result of this act, use of water for agriculture will be systematically reduced and financial constraints will be used to encourage efficiency in water use. Management alternatives will look at increasing the water supply through various augmentation schemes and decreasing the water demand through conservation and water-use pricing. The long-term goal in three areas of greatest overdraft is to reach a "safe yield" condition, in which withdrawal is balanced by recharge, by the year 2025 (Arizona Groundwater Management Study Commission, 1980).

The inequality of supply and demand resulted in ground-water mining from 1940 to 1980 and continues today (1993). In an attempt to bring the supply side of the equation into better balance with the demand side, water from the Colorado River has been imported to the central part of Arizona since 1985. Other methods of augmentation are being studied and include increasing natural recharge, artificial recharge, watershed management, and cloud seeding. At the same time, decreasing the demand side of the equation is being pursued. Approaches being studied include increased irrigation efficiency, including growing crops that consume less water, and the use of level-field and drip irrigation; conservation measures; and reuse of sewage effluent and other water of impaired quality by industry and the public.

\section{SELECTED REFERENCES}

Anderson, T.W., 1968, Electrical-analog analysis of ground-water depletion in central Arizona: U.S. Geological Survey WaterSupply Paper 1860, $21 \mathrm{p}$.

1972, Electrical-analog analysis of the hydrologic system, Tucson basin, southeastern Arizona: U.S. Geological Survey Water-Supply Paper 1939-C, 34 p.

1979, Development of ground-water models of alluvial basins in south-central Arizona, in Proceedings of the 23rd Annual Arizona Water Symposium: Arizona Department of Water Resources Report 2, p. 13-17.

1980, Study plan for the regional aquifer-system analysis of alluvial basins in south-central Arizona and adjacent States: U.S. Geological Survey Open-File Report 80-1197, 22 p.

-1983, Implications of deep percolation to ground-water systems in south-central Arizona based on numerical-model studies, in Proceedings of the Deep Percolation Symposium, October 26, 1982: Arizona Department of Water Resources Report 4 , p. $30-40$.

1984, Southwest Alluvial Basins, RASA study-An overview, in Replogle, J.A., and Renard, K.G., eds., Water today and tomorrow: Specialty Conference, Irrigation and Drainage Division of the American Society of Civil Engineers, Flagstaff, Arizona, July 24-26, 1984, Proceedings, p. 606-613.

-1985 , Aquifer characteristics and hydrologic processes in alluvial basins of south-central Arizona, U.S.A., in Improvement in the use of ground water in agriculture: Second International Conference, March 13-14, 1985, Torreon, Coah., Mexico, p. 87-104.

1986a, Hydrologic setting, objectives, and approach of the Southwest Alluvial Basins, RASA study, in Anderson, T.W., and Johnson, A.I., eds., Regional aquifer systems of the United States, Southwest alluvial basins of Arizona: American Water Resources Association Monograph Series 7, p. 5-16.

1986b, Geohydrology of the Southwest alluvial basins, Arizona, in Anderson, T.W., and Johnson, A.I., eds., Regional aquifer systems of the United States, Southwest alluvial basins of Arizona: American Water Resources Association Monograph Series 7, p. 99-111.

-1986c, Southwest alluvial basins regional aquifer-systems study in southern and central Arizona and parts of adjacent States, in Sun, Ren Jen, ed., Regional Aquifer-System Analysis Program of the U.S. Geological Survey, summary of projects, 1974-84: U.S. Geological Survey Circular 1002, p. 116-131.

Anderson, T.W., and Freethey, G.W., in press, Simulation of ground-water flow in alluvial basins in south-central Arizona and parts of adjacent States: U.S. Geological Survey Professional Paper 1406-D.

Anderson, T.W., Freethey, G.W., and Tucci, Patrick, 1992, Geohydrology and water resources of alluvial basins in south-central Arizona and parts of adjacent States: U.S. Geological Survey Professional Paper 1406-B, $67 \mathrm{p}$.

Anderson, T.W., Welder, G.E., Lesser, Gustavo, and Trujillo, A., 1988, Region 7, Central Alluvial Basins, in Back, William, Rosenshein, J.S., and Seaber, P.R., eds., Geology of North America-Hydrogeology: Boulder, Colorado, Geological Society of America, v. O-2, p. 81-86.

Anderson, T.W., and White, N.D., 1986, Arizona surface-water resources, in Moody, D.W., Chase, E.B., and Aronson, D.A., compilers, National water summary, 1985-Hydrologic events and surface-water resources: U.S. Geological Survey Water-Supply Paper 2300, p. 146-150.

Arizona Groundwater Management Study Commission, 1980, Final report: Phoenix, Arizona Groundwater Management Study Commission report, $49 \mathrm{p}$.

Arizona Water Commission, 1975, Phase I, Arizona State Water Plan-Inventory of resources and uses: Phoenix, State of Arizona, Arizona Water Commission report, $224 \mathrm{p}$.

Bedinger, M.S., Anderson, T.W., and Langer, W.H., 1984, Maps showing ground-water units and withdrawal, Basin and Range Province, Arizona: U.S. Geological Survey Water-Resources Investigations Report 83-4114-A, 2 sheets.

Bedinger, M.S., Langer, W.H., and Reed, J.E., 1985, Synthesis of hydraulic properties of rocks in the Basin and Range Province, Southwestern United States: U.S. Geological Survey WaterSupply Paper 2310, p. 35-43.

Briggs, P.C., and Nemecek, E.A., 1986, Technical aspects of Arizona groundwater law, in Anderson, T.W., and Johnson, A.I, eds., Regional aquifer systems of the United States, Southwest alluvial basins of Arizona: American Water Resources Association Monograph Series 7, p. 93-98.

Brown, S.G., 1976, Preliminary maps showing ground-water resources in the Lower Colorado River region, Arizona, Nevada, New Mexico, and Utah: U.S. Geological Survey Hydrologic Investigations Atlas HA-542, 3 sheets.

Burbey, T.J., and Prudic, D.E., 1991, Conceptual evaluation of regional ground-water flow in the carbonate-rock province of the Great Basin, Nevada, Utah, and adjacent States: U.S. Geological Survey Professional Paper 1409-D, 84 p.

Cuff, M.K., and Anderson, S.R., 1987, Ground-water conditions in Avra Valley, Pima and Pinal Counties, Arizona-1985: U.S. 
Geological Survey Water-Resources Investigations Report 874192,3 sheets.

Dane, C.H., and Bachman, G.O., 1965, Geologic map of New Mexico: U.S. Geological Survey, scale 1:500,000, 1 sheet.

Daniel, D.L., 1981, Maps showing total dissolved-solids content of ground water in Arizona: Arizona Department of Water Resources, Hydrologic Map Series Report 2, scale 1:1,000,000, 2 sheets.

Davidson, E.S., 1973, Geohydrology and water resources of the Tucson basin, Arizona: U.S. Geological Survey Water-Supply Paper 1939-E, $81 \mathrm{p}$.

Davis, A.P., 1897, Irrigation near Phoenix, Arizona: U.S. Geological Survey Water-Supply Paper 2, 98 p.

DeCook, K.J., and Wilson, L.G., 1980, Ground-water recharge from urban runoff and irrigation returns, in Proceedings of the Deep Percolation Symposium, May 1-2, 1980: Arizona Department of Water Resources Report 1, p. 37-52.

Eaton, G.P., Peterson, D.L., and Schumann, H.H., 1972, Geophysical, geohydrological, and geochemical reconnaissance of the Luke Salt body, central Arizona: U.S. Geological Survey Professional Paper 753, $28 \mathrm{p}$.

Epstein, V.J., 1987, Hydrologic and geologic factors affecting land subsidence near Eloy, Arizona: U.S. Geological Survey WaterResources Investigations Report 87-4173, $28 \mathrm{p}$.

Evans, L.G., and Haimson, J.S., 1982, Swab/RASA aquifer parameter study: Arizona Department of Water Resources, final report for U.S. Geological Survey contract 14-08-0001-18268, 21 p.

Fenneman, N.M., 1931, Physiography of western United States: New York, McGraw-Hill, 534 p.

Fennessy, P.J., Carter, K.G., and Keith, S.J., 1980, Summary of literature information on recharge in arid-semiarid basins: Tucson, University of Arizona, Water Resources Research Center report, $259 \mathrm{p}$.

Fields, R.L., 1986, Data-processing activities of the Southwest Alluvial Basins, RASA study, in Anderson, T.W., and Johnson, A.I., eds., Regional aquifer systems of the United States, Southwest alluvial basins of Arizona: American Water Resources Association Monograph Series 7, p. 17-23.

Fields, R.L., and Vetter, E.F., 1984, A data-management system for use in a ground-water modeling and resources evaluation environment: U.S. Geological Survey Water-Resources Investigations Report 84-4014, $227 \mathrm{p}$

Freethey, G.W., 1982, Hydrologic analysis of the upper San Pedro basin from the Mexico-United States international boundary to Fairbank, Arizona: U.S. Geological Survey Open-File Report 82-752, $64 \mathrm{p}$

1984a, Ground-water modeling, alluvial basins of Arizona, in Replogle, J.A., and Renard, K.G., eds., Water today and tomorrow: Specialty Conference, Irrigation and Drainage Division of the American Society of Civil Engineers, Flagstaff, Arizona, July 24-26, 1984, Proceedings, p. 675-682.

$1984 \mathrm{~b}$, Considerations in modeling ground-water flow in the alluvial basins of Arizona, in Anderson, T.W., and Johnson, A.I., eds., Regional aquifer systems of the United States, Southwest alluvial basins of Arizona: American Water Resources Association Monograph Series 7, p. 57-67.

Freethey, G.W., and Anderson, T.W., 1986, Predevelopment hydrologic conditions in the alluvial basins of Arizona and adjacent parts of California and New Mexico: U.S. Geological Survey Hydrologic Investigations Atlas HA-664, 3 sheets.

Freethey, G.W., Pool, D.R., Anderson, T.W., and Tucci, Patrick, 1986, Generalized distribution of aquifer lithology in the alluvial basins of Arizona and adjacent parts of California and New Mexico: U.S. Geological Survey Hydrologic Investigations Atlas HA-663, 4 sheets.
Graf, C.G., 1980, Maps showing ground-water conditions in the Harquahala Plain area, Maricopa and Yuma Counties, Arizona-1980: Arizona Department of Water Resources, Hydrologic Map Series Report 1, scale 1:125,000, 3 sheets.

Halpenny, L.C., and others, 1952, Ground water in the Gila River basin and adjacent areas, Arizona-A summary: U.S. Geological Survey open-file report, $224 \mathrm{p}$.

Harshbarger, J.W., Lewis, D.D., Skibitzke, H.E., Heckler, W.L., and Kister, L.R., 1966, Arizona water: U.S. Geological Survey Water-Supply Paper 1648, 85 p.

Haury, E.W., 1976, The Hohokam-Desert farmers and craftsmen: Tucson, University of Arizona Press, $412 \mathrm{p}$.

Healey, D.L., 1970, Calculated in-situ bulk densities from subsurface gravity observations and density logs, Nevada Test Site and Hot Creek Valley, Nye County, Nevada: U.S. Geological Survey Professional Paper 700-B, p. B52-B62.

Hem, J.D., and Robertson, F.N., 1987, Hydrogeochemistry of ground-water recharge in alluvial aquifers, southern Arizona, in Let's get moving, Third symposium on artificial recharge of ground water in Arizona, May 20-21, 1987, Tempe, Arizona, Proceedings: Salt River Project, Phoenix, and University of Arizona, p. 30-51.

Holzer, T.L., 1980, Reconnaissance maps of earth fissures and land subsidence, Bowie and Willcox areas, Arizona: U.S. Geological Survey Miscellaneous Field Studies Map MF-1156, scale $1: 24,000,2$ sheets.

Keith, S.J., Paylore, Patricia, DeCook, K.J., and Wilson, L.G., 1982, Bibliography on ground-water recharge in arid and semiarid areas: Tucson, University of Arizona, Water Resources Research Center report, $149 \mathrm{p}$.

Kisser, K.G., and Haimson, J.S., 1981, Estimations of aquifer characteristics using drillers' logs: Arizona and Nevada Academy of Sciences, Proceedings of 1981 meeting of American Water Resources Association and Hydrology Section, May 1-2, 1981, v. 11, p. 112-116.

Kister, L.R., 1973, Quality of ground water in the Lower Colorado River region, Arizona, Nevada, New Mexico, and Utah: U.S. Geological Survey Hydrologic Investigations Atlas HA-478, scale $1: 1,000,000,2$ sheets.

Konieczki, A.D., and English, C.S., 1979, Maps showing ground-water conditions in the lower Santa Cruz area, Pinal, Pima, and Maricopa Counties, Arizona-1977: U.S. Geological Survey WaterResources Investigations Report 79-56, scale 1:125,000, 4 sheets.

Laney, R.L., 1979, Geohydrologic reconnaissance of Lake Mead recreation area-Temple Bar to Grand Wash Cliffs, Arizona: U.S. Geological Survey Open-File Report 79-688, 71 p.

Laney, R.L., Raymond, R.H., and Winikka, C.C., 1978, Maps showing water-level declines, land subsidence, and earth fissures in south-central Arizona: U.S. Geological Survey Water-Resources Investigations Report 78-83, 2 sheets.

Langer, W.H., Mulvihill, D.A., and Anderson, T.W., 1984, Maps showing ground-water levels, springs, and depth to ground water, Basin and Range Province, Arizona: U.S. Geological Survey Water-Resources Investigations Report 83-4114-B, 2 sheets.

Leake, S.A., and Prudic, D.E., 1988, Documentation of a computer program to simulate aquifer-system compaction using the modular finite-difference ground-water flow model: U.S. Geological Survey Open-File Report 88-482, 80 p.

Leonard, R.J., 1929, An earth fissure in southern Arizona: Journal of Geology, v. 37, no. 8, p. 765-774.

Lister, R.H., and Lister, F.C., 1983, Those who came before: Tucson, University of Arizona Press, $184 \mathrm{p}$

Mattick, R.E., Olmsted, F.H., and Zohdy, A.A.R., 1973, Geophysical studies in the Yuma area, Arizona and California: U.S. Geological Survey Professional Paper 726-D, 36 p. 
Meinzer, O.E., and Kelton, F.C., 1913, Geology and water resources of Sulphur Spring Valley, Arizona, with a section on Agriculture by R.H. Forbes: U.S. Geological Survey Water-Supply Paper 320, $231 \mathrm{p}$.

Oppenheimer, J.M., and Sumner, J.S., 1980, Regional geophysics assessment of southwest alluvial basins: University of Arizona, final report for U.S. Geological Survey contract 14-08$0001-18228,50 \mathrm{p}$.

-1981, Gravity modeling of the basins in the Basin and Range Province, Arizona: Arizona Geological Society Digest, v. 13 , p. 111-115.

Peirce, H.W., 1974, Thick evaporite deposits in the Basin and Range Province, Arizona, in Fourth Symposium on Salt: Cleveland, Ohio, Northern Ohio Geological Society, p. 47-55.

Poland, J.F., 1981, Subsidence in United States due to groundwater withdrawal: American Society of Civil Engineers, Journal of the Irrigation and Drainage Division, v. 107, no. IR2, p. 115-135.

Poland, J.F., Lofgren, B.E., and Riley, F.S., 1972, Glossary of selected terms useful in studies of the mechanics of aquifer systems and land subsidence due to fluid withdrawal: U.S. Geological Survey Water-Supply Paper 2025, 9 p.

Pool, D.R., 1984, Aquifer geology of alluvial basins of Arizona, in Replogle, J.A., and Renard, K.G., eds., Water today and tomorrow: Specialty Conference, Irrigation and Drainage Division of the American Society of Civil Engineers, Flagstaff, Arizona, July 24-26, 1984, Proceedings, p. 683-690.

1986, Aquifer geology of alluvial basins of Arizona, in Anderson, T.W., and Johnson, A.I., eds., Regional aquifer systems of the United States, Southwest alluvial basins of Arizona: American Water Resources Association Monograph Series 7, p. 2536.

-1987, Geohydrology of McMullen Valley, west-central Arizona: U.S. Geological Survey Water-Resources Investigations Report 87-4041, $51 \mathrm{p}$.

Robertson, F.N., 1984a, Isotopic content of ground water along the Colorado River in Arizona and California [abs.]: Geological Society of America Abstracts with Programs, 97th annual meeting, v. 16 , no. 6 , p. 636 .

- 1984b, Trace elements in ground water in southern Arizona [abs.], in Replogle, J.A., and Renard, K.G., eds., Water today and tomorrow: Specialty Conference, Irrigation and Drainage Division of the American Society of Civil Engineers, Flagstaff, Arizona, July 24-26, 1984, Proceedings, p. 674.

$1984 \mathrm{c}$, Solubility controls of fluorine, barium, and chromium in ground water in alluvial basins of Arizona, in Hitchon, Brian, and Wallick, E.I., eds., Practical applications of ground water geochemistry: National Water Well Association, Proceedings, First Canadian-American Conference on Hydrogeology, June 22-26, 1984, Banff, Alberta, Canada, p. 96-102.

1986a, Occurrence and solubility controls of trace elements in ground water in alluvial basins of Arizona, in Anderson, T.W., and Johnson, A.I., eds., Regional aquifer systems of the United States, Southwest alluvial basins of Arizona: American Water Resources Association Monograph Series 7, p. 69-80.

$-1986 \mathrm{~b}$, Origin and chemistry of ground water along the Colorado River in Arizona, Nevada, and California [abs.]: Journal of the Arizona-Nevada Academy of Science, v. 21, proceedings supplement, p. 56.

-1989a, Ground-water geochemistry and information transfer in alluvial basins in Arizona: 28th International Geological Congress, July 9-19, 1989, Abstracts, v. 2, p. 709-710.

$1989 \mathrm{~b}$, Arsenic in ground water under oxidizing conditions, southwest United States: Environmental Geochemistry and Health, v. 11, no. 3/4, December 1989, p. 171-185. -1989c, Prediction of water quality through geochemical modeling in undeveloped areas in the desert Southwest [abs.], in U.S. Geological Survey Second National Symposium on Water Quality, Abstracts of the Technical Sessions, Orlando, Florida, November 12-17, 1989: U.S. Geological Survey Open-File Report $89-409$, p. $77-78$.

1990, Trace constituents in ground water in alluvial basins in Arizona-source, controls, and prediction [abs.], in Programme of the Eighth Annual European Meeting, Society for Environmental Geochemistry and Health: Reading, England, Reading University, April 1-4, 1990.

1991, Geochemistry of ground water in alluvial basins in Arizona and adjacent States: U.S. Geological Survey Professional Paper 1406-C, $90 \mathrm{p}$.

Robertson, F.N., and Garrett, W.B., 1986, Distribution of fluoride in the ground water in alluvial basins of Arizona and adjacent parts of California, Nevada, and New Mexico: U.S. Geological Survey Hydrologic Investigations Atlas HA-665, scale 1:500,000, 3 sheets.

Scarborough, R.B., and Peirce, H.W., 1978, Late Cenozoic basins of Arizona, in Callender, J.F., Wilt, J.C., and Clemons, R.E., eds., The Land of Cochise: New Mexico Geological Society Guidebook, 29th Field Conference, p. 253-259.

Schmidt, K.D., 1980, Ground-water quality impact determined from well sampling, in Proceedings of the Deep Percolation Symposium, May 1-2, 1980: Arizona Department of Water Resources Report 1, p. 74-84.

Schumann, H.H., and Genualdi, R.B., 1986, Land subsidence, earth fissures, and water-level change in southern Arizona: Arizona Bureau of Geology and Mineral Technology, Map 23, scale 1:1,000,000, 1 sheet.

Schumann, H.H., Laney, R.L., and Cripe, L.S., 1986, Land subsidence and earth fissures caused by ground-water depletion in southern Arizona, in Anderson, T.W., and Johnson, A.I., eds., Regional aquifer systems of the United States, Southwest alluvial basins of Arizona: American Water Resources Association Monograph Series 7, p. 81-91.

Schumann, H.H., and Poland, J.F., 1970, Land subsidence, earth fissures, and ground-water withdrawal in south-central Arizona, U.S.A., in Land subsidence: Tokyo, International Association of Scientific Hydrology Publication 88, v. 1, p. 295302.

Schumann, H.H., Tosline, D.J., and Wrege, B.M., 1984, Occurrence and prediction of earth-fissure hazards caused by ground-water depletion in south-central Arizona, U.S.A. [abs.], in Replogle, J.A., and Renard, K.G., eds., Water today and tomorrow: Specialty Conference, Irrigation and Drainage Division of the American Society of Civil Engineers, Flagstaff, Arizona, July 24-26, 1984, Proceedings, p. 673.

Shafiqullah, M., Damon, P.E., Lynch, D.J., Reynolds, S.J., Rehrig, W.A., and Raymond, R.H., 1980, K-Ar geochronology and geologic history of southwestern Arizona and adjacent areas: Arizona Geological Society Digest, v. 12, p. 201-260.

Small, G.G., 1983, Ground-water quality impacts of cascading water in the Salt River Project area, in Proceedings of the Deep Percolation Symposium, October 26, 1982: Arizona Department of Water Resources Report 4, p. 41-47.

Thompson, T.H., Nuter, Janet, and Anderson, T.W., 1984, Maps showing distribution of dissolved solids and dominant chemical type in ground water, Basin and Range Province, Arizona: U.S. Geological Survey Water-Resources Investigations Report 83-4114-C, 4 sheets.

Trescott, P.C., 1975, Documentation of finite-difference model for simulation of three-dimensional ground-water flow: U.S. Geological Survey Open-File Report 75-438, 32 p. 
Trescott, P.C., and Larson, S.P., 1976, Documentation of finite-difference model for simulation of three-dimensional groundwater flow: U.S. Geological Survey Open-File Report 76-591, 21 p. [Supplement to Open-File Report 75-438.]

Tucci, Patrick, 1982, Use of three-dimensional model for the analysis of the ground-water flow system in Parker Valley, Arizona and California: U.S. Geological Survey Open-File Report 82$1006,54 \mathrm{p}$.

1984, Surface resistivity studies for water-resources investigations, near Tucson, Arizona: Proceedings, National Water Well Association-U.S. Environmental Protection Agency Conference on surface and borehole geophysical methods in ground-water investigations, San Antonio, Texas, February 69, 1984, p. 92-106.

1989, Geophysical methods for water-resources studies in southern and central Arizona, in Proceedings of the Symposium on the Application of Geophysics to Engineering and Environmental Problems: Denver, Colorado, Society of Engineering and Mineral Exploration Geophysicists, p. 368-383.

Tucci, Patrick, and Pool, D.R., 1982, Borehole gravity surveys in basin-fill deposits of central and southern Arizona: U.S. Geological Survey Open-File Report 82-473, 23 p.

1986, Use of geophysics studies in the alluvial basins of Arizona, in Anderson, T.W., and Johnson, A.I., eds., Regional aquifer systems of the United States, Southwest alluvial basins of Arizona: American Water Resources Association Monograph Series 7, p. 37-56.

Tucci, Patrick, Schmoker, J.W., and Robbins, S.L., 1983, Density of basin-fill deposits calculated from borehole-gravity data in four basins in central and southern Arizona [abs.]: Society of Explo- ration Geophysicists, Expanded Abstracts with Biographies, 1983 Technical Programs, p. 28-31.

1984, Density of basin-fill deposits calculated from boreholegravity data in four basins in central and southern Arizona [abs.]: Geophysics, v. 49, no. 5, May 1984, p. 595.

U.S. Environmental Protection Agency, 1977, National interim primary drinking-water regulations: U.S. Environmental Protection Agency Report EPA-470/9-76-003, 159 p.

U.S. Geological Survey, 1982, Annual summary of ground-water conditions in Arizona, spring 1980 to spring 1981: U.S. Geological Survey Open-File Report 82-368, scale 1:1,000,000, 2 sheets.

Valley National Bank, 1983, Arizona statistical review: Phoenix, Valley National Bank of Arizona, Economic Research Department, 39th annual edition, $76 \mathrm{p}$.

White, N.D., and Anderson, T.W., 1985, Arizona ground-water resources, in National water summary, 1984-Hydrologic events, selected water-quality trends, and ground-water resources: U.S. Geological Survey Water-Supply Paper 2275, p. 135-140.

Wilson, E.D., Moore, R.T., and Cooper, J.R., 1969, Geological map of Arizona: Arizona Bureau of Mines map, scale 1:500,000, 1 sheet.

Wilson, L.G., DeCook, K.J., and Neuman, S.P., 1980, Regional recharge research for southwest alluvial basins: Tucson, University of Arizona, Water Resources Research Center report, 389 p.

Winikka, C.C., and Wold, P.D., 1977, Land subsidence in central Arizona: International Association of Scientific Hydrology Publication 121, p. 95-103.

Winograd, I.J., and Robertson, F.N., 1982, Deep oxygenated ground water-Anomaly or common occurrence?: Science, v. 216, p. 1227-1230. 



\section{SELECTED SERIES OF U.S. GEOLOGICAL SURVEY PUBLICATIONS}

\section{Periodicals}

Earthquakes \& Volcanoes (issued bimonthly).

Preliminary Determination of Epicenters (issued monthly).

\section{Technical Books and Reports}

Professional Papers are mainly comprehensive scientific reports of wide and lasting interest and importance to professional scientists and engineers. Included are reports on the results of resource studies. and of topographic, hydrolugic, and geologic investigations. They also include collections of related papers addressing different aspects of a single scientific topic.

Bulletins contain significant data and interpretations that are of las'ing scientific interest but are genetally more limited in scope or geographic coverage than Protessional Papers. They include the results of resource studies and of geologic and topographic investigations, as weil as collections of short papers related to a specific topic.

Water-Supply Papers are comprehensive reports that present significant interpretive results of hydrologic investigations of wide interest to professional geologists. hydrologists, and engineers. The series covers investigations in all phase's of hydrology. including hydrogeolugy, availability of water. quality of water, and use of water.

Circulars present administrative information or important scientific: information of wide popular interest in a format designed for distrihution at no cost to the public. Information is usually of vort-tem interest.

Water-Resource Investigations Reports are papers of an interpretive nature made available to the public outside the formal USGS publications series. Copies are reproduced on request unlike formal USGS publications. and they are also available for public inspection at depositories indicated in ISGS catalogs.

Open-File Reports include unpublished manuscript reports, maps. and other material that are made available for public consultation at depositories. They are a nonpermanent form of publication that may be cited in other publications as sources of intormation.

\section{Maps}

Geologic Quadrangle Maps are multi:olor geologie maps on 10poglaphic bases in $71 / 2$ - or 15 -minute quadrangle formats heales mainly $1: 24.000$ or $1: 62.5000$ showing bedrock. surficul, or engineering geo!ogy. Maps generaily melude bref texts; ome maps include structure and columnar sectuons ont:

Geophysical Investigations Maps ane on topographe or manime! ric basen at harous scales; thes show jesults of survers liang

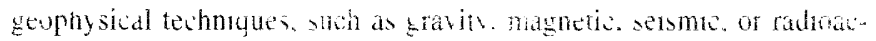

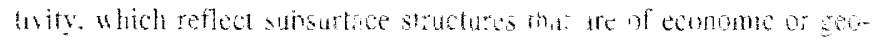

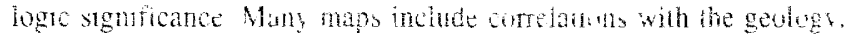

Miscellaneous Investyations Series Maps are on planimetro of lopographic bases of reguid and irregular aras at arous seales. hev present a wide ariety uf iormat and stober matter. The sertes tho include, 7 1/2-minute quatongle photogevloge maps on planmetic

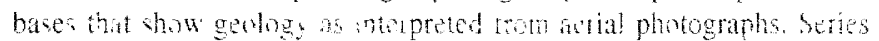
abo inclutes maps of Mats and the Moon
Coal Investigations Maps are geologic maps on topographic or planimetric bases at various scales showing bedrock or surficial geology, stratigraphy, and structural relations in certain coal-resource areas.

Oil and Gas Investigations Charts show stratigraphic information for certain oil and gas fields and other areas having petroleum potential.

Miscellaneous Field Studies Maps are multicolor or black-andwhite maps on topographic or planimetric bases on quadrangle or irregular areas at various scales. Pre-1971 maps show bedrock geology in relation to specific mining or mineral-deposit problems; post-1971 maps are primarily black-and-white maps on various subjects, such as environmental studies or wilderness mineral investigations.

Hydrologic Investigations Atlases are multicolor or black-andwhite maps on topographic or planimetric bases presenting a wide range of genhydrologic data of both regular and irregular areas; principal scaie is 1:24.000, and regional studies are at 1:250,000 scale or smaller.

\section{Catalogs}

Pemanent catalogs, as well as some others, giving comprehensive listings of L.S. Geological Survey publications are available under the conditions indicated below from the U.S. Geological Survey, Books and Onen-File Reports Sales. Federal Center, Box 25286, Denver, CO 80225 isee latest Price and Arailability List.)

"Publications of the Geological Survey, 1879-1961" may be purchased $h$ y mail and over the counter in paperback hook form and as a set of nicrufiche.

"Publications of the Geological Survey, 1962-1970" may be purchased by mall and over the counter in paperback book form and as a set of nuicrofiche.

"Publications of the Geological Survey, 1971-1981" may be purchased by mail and over the counter in paperback book form (two solunes, publications listing and index) and as a set of microfiche.

Supplements for 1982, 1983,1984, 1985, 1986, and for subsequent years sinee the last permanent catalog may be purchased by mail and on the counter in paperback book form.

State catalogs, "List of UI.S. Geological Survey Geologic and Hater-Supply Reports and Maps For (State)." may be purchased by mail and over the counter in paperback booklet form only.

"Price and Availability List of U.S. Geological Survey Publications," issued annually, is available free of charge in paperback booklet iorm only

Selected copies of a monthly catalog "New Publications of the is Celogical Survey" are available free of charge by mail or may b: ohrined over the counter in paperback booklet form only. Those whing a tree subscription to the monthly catalog "New Publications of the U.S. Geological Survey" should write to the U.S. Geological Surve 582 National Center, Reston, VA 22092.

Note.-Prices of Government publications listed in older catalogs, amoums: ments, and publications may be incorrect. Therefore, the prices charged way differ from the prices in catalogs, announcements, and publications. 
